Bäckström, Caroline. Evolución y tendencias del rentismo petrolero en el ecuador 2001-2010.

\title{
EVOLUCIÓN Y TENDENCIAS DEL RENTISMO PETROLERO EN EL ECUADOR 2001-2010
}

\section{EVOLUTION AND TENDENCIES OF THE PETRO-RENTIER STATE IN ECUADOR 2001-2010}

\author{
CAROLINE BÄCKSTRÖM \\ Universidad Complutense de Madrid \\ cbackstrom@ucm.estumail.es
}

Fecha de recepción: julio de 2012

Fecha de aceptación: mayo de 2013

\begin{abstract}
RESUMEN
Un estado rentista se caracteriza por una estructura económica poco diversificada y polarizada hacia el petróleo, fiscalidad petrolera alta y gestión de la renta regida bajo criterios políticos, además de una economía vulnerable ante las fluctuaciones del precio de petróleo. El presente trabajo concluye que estos rasgos se intensificaron en el Ecuador como consecuencia del cambio político del 2007. En particular se fortalecieron rasgos del sector público y objetivos de la gestión de la renta además de que aumentó la vulnerabilidad de la demanda a la evolución del precio de petróleo. Así, a pesar de los esfuerzos del gobierno por aumentar la captación de ingresos no petroleros e invertir en capital, no se ha logrado contrarrestar un mayor grado de rentismo.
\end{abstract}

PALABRAS CLAVE: petróleo, rentismo, Ecuador, economía política, desarrollo.

\begin{abstract}
A rentier state is characterized by having a non-diversified economic structure that is biased towards petroleum, high representation of oil income in total public income, rent management ruled by political criteria and high economic vulnerability to changes in oil prices. This paper concludes that these characteristics in Ecuador were intensified as a consequence of the political change in 2007. Particularly features related to the public sector and the objectives of rent management where deepened, but the vulnerability of demand to fluctuations in oil prices did also increase. So, in spite of the government's efforts to increase non-oil income and invest in capital, a higher level of rentierism has not been counteracted.
\end{abstract}

KEYWORDS: petroleum, rentier state, Ecuador, political economy, development.

JEL: 011, O20, O54, P28, Q33.

\section{INTRODUCCIÓN}

La teoría del estado rentista consiste en una serie de ideas sobre los procesos de desarrollo socio económico y la naturaleza del Estado en economías en las que la renta externa tiene un peso importante (Yates, 1996). Esta teoría fue tomando fuerza 
Bäckström, Caroline. Evolución y tendencias del rentismo petrolero en el ecuador 2001-2010.

en la década de los setenta siendo para esto clave dos eventos: la declaración de la Organización de Países Exportadores de Petróleo (OPEP) del 1968, y los picos en el precio de petróleo de los años setenta. En dicha declaración se resaltó el derecho de los países a la soberanía del uso de sus recursos naturales para fomentar el desarrollo nacional (OPEP, 2011b; Mañé Estrada y de la Cámara Arilla, 2004; Machín Álvarez, 2010). Sin embargo, debido al debilitamiento del poder de la OPEP, el fracaso de las estrategias de desarrollo de estos países junto con la progresiva desaparición de las condiciones de rentismo, en la actualidad este término ha sido remplazado por términos como países productores de petróleo, países exportadores de petróleo o estados ricos en recursos naturales (Mañé Estrada y de la Cámara Arilla, 2004). Pero ninguno de estos términos ofrece componentes para identificar si en un país rico en recursos naturales, productor y exportador de petróleo se dan condiciones de rentismo, es decir si la estructura económica es poco diversificada y polarizada hacia el petróleo, si la fiscalidad petrolera es alta y la gestión de la renta se rige bajo criterios políticos y si la economía es altamente vulnerable antes las fluctuaciones del precio de petróleo. ${ }^{1}$ Así, la teoría del rentismo resulta útil para entender la estrategia política y económica de los dirigentes de un país en relación al proceso de desarrollo económico social. Por esta razón, este trabajo recupera el concepto de rentismo ya que nos puede ayudar a entender recientes acontecimientos políticos y económicos en el Ecuador.

El sector petrolero ecuatoriano obtuvo un creciente protagonismo en la economía con el descubrimiento de nuevos yacimientos en los años sesenta y con el incremento de los ingresos petroleros causado por los picos de petróleo en los años setenta, convirtiéndose en el pilar de su patrón primario exportador. En los años ochenta el auge petrolero se terminó debido a la caída del precio de petróleo y a la reversión del flujo de préstamos que anteriormente se había dirigido a países en desarrollo como el Ecuador. En este contexto se empiezan a aplicar políticas de ajuste de inspiración neoliberal liderado por el ideario del Consenso de Washington ${ }^{2}$, lo cual, junto con otros factores, dio lugar al agravamiento de la crisis económica del país y a que se diera marcha atrás en las políticas nacionalistas del 1972. Así, el Estado fue cediendo cada vez una mayor parte de la renta petrolera para atraer inversiones extranjeras y la empresa petrolera estatal fue debilitada. Durante los años siguientes el sector petrolero ecuatoriano se caracterizó por el dominio de las empresas privadas, apoyadas por un Estado inestable ${ }^{3}$ y corrupto. Además hasta el 2005, el gasto público fue limitado debido a un fondo petrolero creado para atender el servicio de la deuda externa (Acosta, 2009).

En el 2007 se dio un cambio político importante en el Ecuador con el triunfo del Movimiento Alianza País (AP), liderado por el economista Rafael Correa, en las elecciones presidenciales del 2006. Los dos planes de desarrollo ${ }^{4}$ de este Gobierno establecen que su "significado más profundo está en la ruptura conceptual que plantean los idearios del Consenso de Washington y con las aproximaciones más

\footnotetext{
${ }^{1}$ Las condiciones del rentismo se explican con más detalle en el apartado 3.

${ }^{2}$ Programa de políticas neoliberales para salir de la crisis económica de los ochenta, desarrollado a partir de una conferencia del Institute of International Economics en Washington en el año 1989.

${ }^{3}$ Tres presidentes fueron derrocados por la presión popular: Abdalá Bucaram (1997), Jamil Mahuad (2000) y Lucio Gutiérrez (2005)

4 "Plan Nacional de Desarrollo 2007-2010- Planificación para la revolución ciudadana" y "Plan Nacional del Buen Vivir 2009-2013-Construyendo un Estado Plurinacional e Intercultural"
} 
Bäckström, Caroline. Evolución y tendencias del rentismo petrolero en el ecuador 2001-2010.

ortodoxas al concepto de desarrollo" (República del Ecuador, 2009, p.5). Así, el objetivo de este Gobierno es impulsar un "proceso revolucionario" para crear una sociedad incluyente, solidaria y equitativa para así construir un "Socialismo del Buen Vivir" (Movimiento Alianza País, 2011a). Para alcanzar este objetivo se han introducido reformas dirigidas a restablecer las capacidades estatales de redistribución de la riqueza, regulación de la economía y planificación del desarrollo social (Movimiento Alianza País, 2011b). En este contexto se ha realizado una restructuración del sector petrolero con el objetivo de aumentar los ingresos públicos provenientes de la exportación de petróleo, lo cual permite al Estado aumentar la inversión y el gasto público.

La hipótesis de este trabajo es que el cambio político del 2007 ha dado lugar a que el grado de rentismo en el Ecuador haya aumentado. Para averiguar si este es el caso, la primera parte del trabajo establece un marco teórico del rentismo donde se describen los principales rasgos de una economía rentista, el cual se utiliza en la segunda parte para analizar la evolución del grado de rentismo en el Ecuador en el periodo 2001-2010.

\section{OBJETIVO Y METODOLOGÍA}

El objetivo de este trabajo es analizar la evolución de los rasgos propios de una economía rentista en el Ecuador durante el periodo 2001-2010. Para esto la teoría del rentismo nos ofrece una serie de características que se deben dar para que un país sea considerado rentista. A partir de este marco se utilizarán indicadores macroeconómicos, contextualizados en los acontecimientos políticos, para evaluar el grado de rentismo. A pesar de que rentismo es un concepto general que se puede aplicar a varios tipos de ingresos externos, este trabajo se centrará en el rentismo asociado con ingresos de la exportación de petróleo.

\section{LA TEORÍA DEL RENTISMO}

En su trabajo sobre rentismo en Irán de 1970, Hossein Mahdavy definió en un sentido amplio el estado rentista como un país que recibe de forma regular cantidades substanciales de renta externa. Estos ingresos son independientes del esfuerzo productivo del país ya que provienen de un proceso de venta de un recurso natural, a menudo poco elaborado, en el mercado internacional. Este es el punto de partida y el elemento central en la teoría rentista porque lo que se analiza es el impacto de la entrada de grandes cantidades de renta, en un periodo corto de tiempo, en la naturaleza del estado. En los años 80, Hazem Beblawi y Giacomo Luciani desarrollan la idea del estado rentista en la que existen importantes comportamientos rentistas relacionadas con un flujo considerable de renta que proviene de fuentes exteriores a la economía nacional. Para estos autores el estado es una combinación de indicadores esenciales que describen la relación entre el Estado y la economía reflejada en la política económica del país. La naturaleza de un Estado rentista se examina principalmente estudiando su tamaño relativo a esa economía, las fuentes y estructuras de sus ingresos, el destino del gasto público y las leyes y regulaciones que afectan la vida económica (Yates, 1996).

Para poder encontrar las causas detrás de dados procesos de desarrollo socio económicos, es necesario analizar tanto la dimensión económica como la política. La 
Bäckström, Caroline. Evolución y tendencias del rentismo petrolero en el ecuador 2001-2010.

causa clave de la evolución de un indicador macroeconómico se puede encontrar en factores políticos al igual que se pueden dar determinados comportamientos políticos dependiendo de cómo se desarrollan ciertos aspectos macroeconómicos. Así también la clasificación de un país como rentista requiere no sólo que se estudien los indicadores macroeconómicos ya que también se tienen que dar determinadas circunstancias políticas y sociales (Mañé Estrada y de la Cámara Arilla, 2004). Beblawi apunta en la misma dirección cuando constata que el rentismo sólo puede persistir a través de mecanismos que garantizan una dada gestión y distribución de la renta. Así, este autor define un país rentista como uno cuya economía se basa en importantes flujos de renta externa que es generada por una pequeña parte de la sociedad y cuyo principal receptor y distribuidor es el gobierno de ese país (Machín Álvarez, 2010). Para Beblawi y Luciani la definición de un país como rentista es cuestión de juicio y no existen países puramente rentistas, pero sí deben predominar situaciones de rentismo (Yates, 1996).

En lo que sigue se hará una selección y resumen de las principales características de un estado rentista, tanto económicas como políticas, ofrecidas por la literatura. Estos rasgos se han dividido en tres ámbitos: primero - la estructura económica y el sector petrolero, segundo - los rasgos relacionados con fiscalidad petrolera y los objetivos de la gestión del sector petrolero y del uso de la renta, y finalmente cuestiones de dependencia y vulnerabilidad ante fluctuaciones del precio de petróleo.

\subsection{La estructura económica y el sector petrolero}

Según Beblawi, en un país rentista la fuente de la renta debe ser externa y sólo una pequeña parte de la sociedad participa en su generación. Así, no todos los países con importantes ingresos externos son rentistas, por ejemplo un país con un amplio sector de turismo no es considerado rentista ya que una gran parte de la población participa en la generación de la renta (Yates, 1996).

Una economía rentista petrolera es prácticamente mono exportadora de petróleo. Cuando se aplica este término se suele hablar de economías primario exportadoras, no diversificadas que exportan petróleo crudo o gas sin elaborar (Mañé Estrada y de la Cámara Arilla, 2004). Aquí asumimos que un país es mono exportador cuando un producto cubre aproximadamente la mitad del total de sus exportaciones.

El sector de petróleo es un componente importante de la estructura productiva de una economía rentista y como contrapartida tiene un amplio sector de servicios que se nutre de importaciones (Mañé Estrada y de la Cámara Arilla, 2004). El sector de comercio se expande dada la demanda de bienes importados, que viene de la escasa capacidad del país de producirlos y de la desventaja en calidad de los bienes domésticos comparada con los importados. Esto se relaciona con lo que Yates denomina "consumo conspicuo", que implica que se consumen bienes con el propósito de comparación individual, teniendo los bienes extranjeros más estatus que los bienes domésticos. Así, un amplio sector de comercio genera un alto nivel de importaciones. Dado que el Estado es el principal receptor y distribuidor de la renta, su aparato burocrático tiende a ser amplificado lo cual también hace crecer al sector de servicios. También tienden a aumentar los servicios relacionados con el sector de petróleo, aunque en el caso de fuerza de trabajo con capacitación 
Bäckström, Caroline. Evolución y tendencias del rentismo petrolero en el ecuador 2001-2010.

adecuada, ésta muchas veces es traída del exterior cuando el país carece de ella (Yates, 1996). Además, las ambiciosas inversiones en infraestructura de un Estado rentista amplifican el sector de la construcción. Así, la escasa capacidad del sector petrolero de generar empleo y la ausencia de fuertes sectores manufactureros intensivos en trabajo hacen que la población se concentre en el sector de servicios en búsqueda de empleo.

En cuanto a la distribución privado-publica del sector de petróleo en una economía rentista, es la empresa nacional petrolera la que predomina, siendo ésta el instrumento clave del Estado rentista y el principal explotador e exportador del petróleo. De esta manera las empresas petroleras extranjeras tienen una importancia reducida en el sector (Machín Álvarez, 2010; Mañé Estrada y de la Cámara Arilla, 2004).

\subsection{Objetivos de la gestión del sector petrolero y fiscalidad petrolera}

En un país rentista tiene que haber un acuerdo de que el Estado debe ser el principal receptor y repartidor de la renta. Luciani habla de "Estados distribuidores" cuya principal función es articular un consenso social alrededor de la captación y distribución de la renta petrolera. Beblawi constata que el gobierno debe ser el principal receptor de la renta, lo cual implica la concentración de la renta en manos de pocos y la vinculación a ella del resto de la sociedad a través de su distribución y uso (Yates, 1996). La captura y distribución de la renta está sujeta a criterios políticos que tienen el objetivo de mantener la dinámica rentista en el tiempo y que legitima la posición del Estado (Machín Álvarez, 2010). Éste, siendo propietario de la empresa nacional petrolera o receptor de la fiscalidad petrolera, funciona como un intermediario entre los que generan la renta y los que la disfrutan (Beblawi y Luciani en Mañé Estrada y de la Cámara Arilla, 2004; y en Yates, 1996). Así, el objetivo de la exportación de petróleo de una economía rentista es obtener el máximo beneficio para la nación, estableciéndose un Estado autónomo que distribuye la renta de forma que se establezca un contrato social (Mañé Estrada y de la Cámara Arilla, 2004).

Autores como Luciani y Mahdavy, ponen énfasis en que un alto peso de los ingresos externos en los ingresos fiscales libera al Estado de la necesidad de extraer ingresos de la economía doméstica. Luciani ofrece así una categorización entre "estados de asignación de recursos" (rentista) y "estados productivos". En el primero los ingresos provienen principalmente de rentas externas y el objetivo de la política económica es el gasto, mientras que en "estados productivos" el objetivo es generar crecimiento económico, ya que los ingresos vienen de la fiscalización de la actividad económica. Luciani considera que un estado es rentista (es decir no productivo) cuando más del $40 \%$ de los ingresos fiscales totales provienen de petróleo u otras fuentes externas y cuando el gasto público representa una parte importante del PIB (Yates, 1996). Independientemente de si se utiliza este criterio del $40 \%$ que ofrece Luciani, la fiscalidad petrolera en un Estado rentista es alta. Otro indicador del grado de rentismo es la de Fiscalidad Relativa Ponderada ${ }^{5}$ (FRP) que, cuanto más elevado es, indica que los ingresos petroleros tienen más peso en los ingresos fiscales que el

\footnotetext{
${ }^{5} \mathrm{FRP}=$ Fiscalidad petrolera / (sector de petróleo/PIB)
} 
Bäckström, Caroline. Evolución y tendencias del rentismo petrolero en el ecuador 2001-2010.

que tiene el sector petrolero en la economía (Mañé Estrada y de la Cámara Arilla, 2004).

Así, los principales instrumentos del Estado rentista son: primero - "unas políticas de alianzas en el marco de la Escena Energética Internacional con el fin de lograr el máximo ingreso posible de sus exportaciones para la nación ", segundo - la gestión de la empresa nacional petrolera, estando ésta en el centro de la lógica rentista, se adapta a los objetivos políticos de recaudar de forma centralizada el máximo de la renta petrolera y, por último - "los ingresos provenientes de las exportaciones petroleras son para el gobierno su principal instrumento de intervención pública y se traducen en políticas de gasto destinados fundamentalmente a legitimar el sistema vigente" (Mañé Estrada y de la Cámara Arilla, 2004, p.77). Por esta razón, la renta petrolera tiende a ser destinada a actividades no productivas. Como constata Beblawi y Luciani, un estado puede ser productivo o acumulativo. El estado rentista se asocia con lo segundo, ya que una economía rentista no produce dinámicas de inversión productiva. Por esta razón es fundamental estudiar hacia donde se va la renta. (Yates, 1996)

\subsection{Dependencia y vulnerabilidad ante las fluctuaciones del precio de petróleo}

Uno de los problemas de países petróleo-rentistas más citados es la alta vulnerabilidad de sus economías ante la evolución del precio de petróleo. Así, en periodos de bonanza el comercio exterior influye de forma importante en el crecimiento del PIB, estando éste vinculado al superávit comercial causado por el fuerte aumento de los ingresos por exportaciones de petróleo. Así, en una economía rentista la evolución del PIB y los componentes de la demanda muestran una alta elasticidad a la evolución del precio de crudo en el mercado internacional (Mañé Estrada y de la Cámara Arilla, 2004).

El hecho de que una economía rentista petrolera es mono exportadora de petróleo hace que los ingresos por exportaciones dependan en gran medida de la evolución del precio de petróleo, por lo cual cuanto más acentuada sea esta característica más volátil será la economía ante las fluctuaciones del precio en el mercado internacional.

Dado el alto nivel de la fiscalidad petrolera, los ingresos públicos son también dependientes del precio de petróleo. Esto dificulta la gestión de las finanzas públicas ya que los ingresos y el gasto públicos fluctúan fuertemente de acuerdo a la evolución de los precios de petróleo en el mercado internacional. En periodos de bonanza, el Estado aumenta sus redes de clientes ya que emprende grandes proyectos de inversión y gasto. Cuando los ingresos públicos disminuyen, el Estado tiene que reducir sus gastos, perdiéndose las redes de clientes, o acudir a endeudamiento para mantener los altos niveles de gasto (Machín Álvarez, 2010). De esta manera también las inversiones públicas se vuelven más elásticas ante el precio de petróleo con un mayor grado de rentismo.

El consumo y la inversión privada son los componentes de la demanda cuya elasticidad se ve menos afectada con un mayor nivel de rentismo. Esto se debe a que la renta llega de forma más limitada a la población y al sector privado. A pesar 
Bäckström, Caroline. Evolución y tendencias del rentismo petrolero en el ecuador 2001-2010.

de que un Estado rentista muchas veces aumenta el gasto en programas sociales, esto rara vez significa que se aumenta de forma importante la capacidad de consumo de la población. Además, el consumo doméstico de petróleo nacional es limitado ya que la mayor parte es producida para la exportación, dejando poco para los consumidores locales (Yates, 1996). El hecho de que un Estado rentista no intente romper con esta condición es clave para entender su naturaleza, ya que tiene que ver con la prioridad que éste otorga al mantenimiento del consenso social que justifica su posición en el poder, siendo proveedor de servicios básicos universales y realizando grandes y visibles proyectos de inversión en infraestructura. Es decir que el Estado rentista no busca fortalecer el sector privado, ya que esto podría amenazar su posición, por lo cual no incentiva el consumo y sobre todo no incentiva la inversión privada.

Resumiendo, ser receptor de grandes flujos de renta externa proveniente de la exportación de petróleo es condición necesaria pero no suficiente para que un país pueda ser considerado rentista. Además de esto, lo que caracteriza en grandes líneas un país petrolero rentista es que su estructura económica es poco diversificada y polarizada hacia el petróleo, la fiscalidad petrolera es alta y la gestión de la renta se rige bajo criterios políticos, además de que la economía es altamente vulnerable ante las fluctuaciones del precio de petróleo.

\section{EVOLUCIÓN DE LOS RASGOS RENTISTAS EN EL ECUADOR 2001-2010.}

\subsection{La estructura económica y el sector petrolero}

\subsubsection{Renta externa proveniente de la exportación de petróleo}

Como se puede ver en el gráfico 1, el peso de las exportaciones petroleras en el PIB del Ecuador aumentó entre 2002 y 2010, pasando de un 12\% a un 36\%. Como consecuencia del pico del precio de petróleo en 2008, ese año llegaron a representar $49 \%$ del PIB. Junto con el hecho de que las exportaciones petroleras en valores absolutos aumentaron (Gráfico 2), podemos constatar que la renta externa proveniente de la exportación de petróleo ha aumentado su importancia en la economía a lo largo del periodo.

Aquí asumimos que un país es mono-exportador cuando un producto cubre aproximadamente la mitad del total de exportaciones, además de que se suele tratar de economías primario exportadoras, que exportan petróleo crudo o gas sin elaborar (Mañé Estrada y de la Cámara Arilla, 2004). Las exportaciones petroleras ecuatorianas dominaron en el total de las exportaciones y aumentaron su peso, pasando del $39 \%$ en el 2002 , al $61 \%$ en el 2008 y al $51 \%$ en el 2009 , periodo en el valor de las exportaciones totales subió (Gráfico 2). El peso de las exportaciones petroleras en las exportaciones totales del Ecuador es bastante más bajo que en países considerados rentistas, como Venezuela, Kuwait y Argelia, pero no es tan bajo como en países exportadores de petróleo que no se consideran rentistas, como Noruega e Indonesia (Mañé Estrada y de la Cámara Arilla, 2004). De las exportaciones petroleras ecuatorianas, un 90\% corresponde a la exportación de crudo y sólo el $10 \%$ son exportaciones de derivados, distribución que se mantiene a lo largo del periodo analizado. Así, las exportaciones de crudo son las que han dirigido el aumento de las exportaciones petroleras en valores absolutos (Gráfico 3). 
Bäckström, Caroline. Evolución y tendencias del rentismo petrolero en el ecuador 2001-2010.
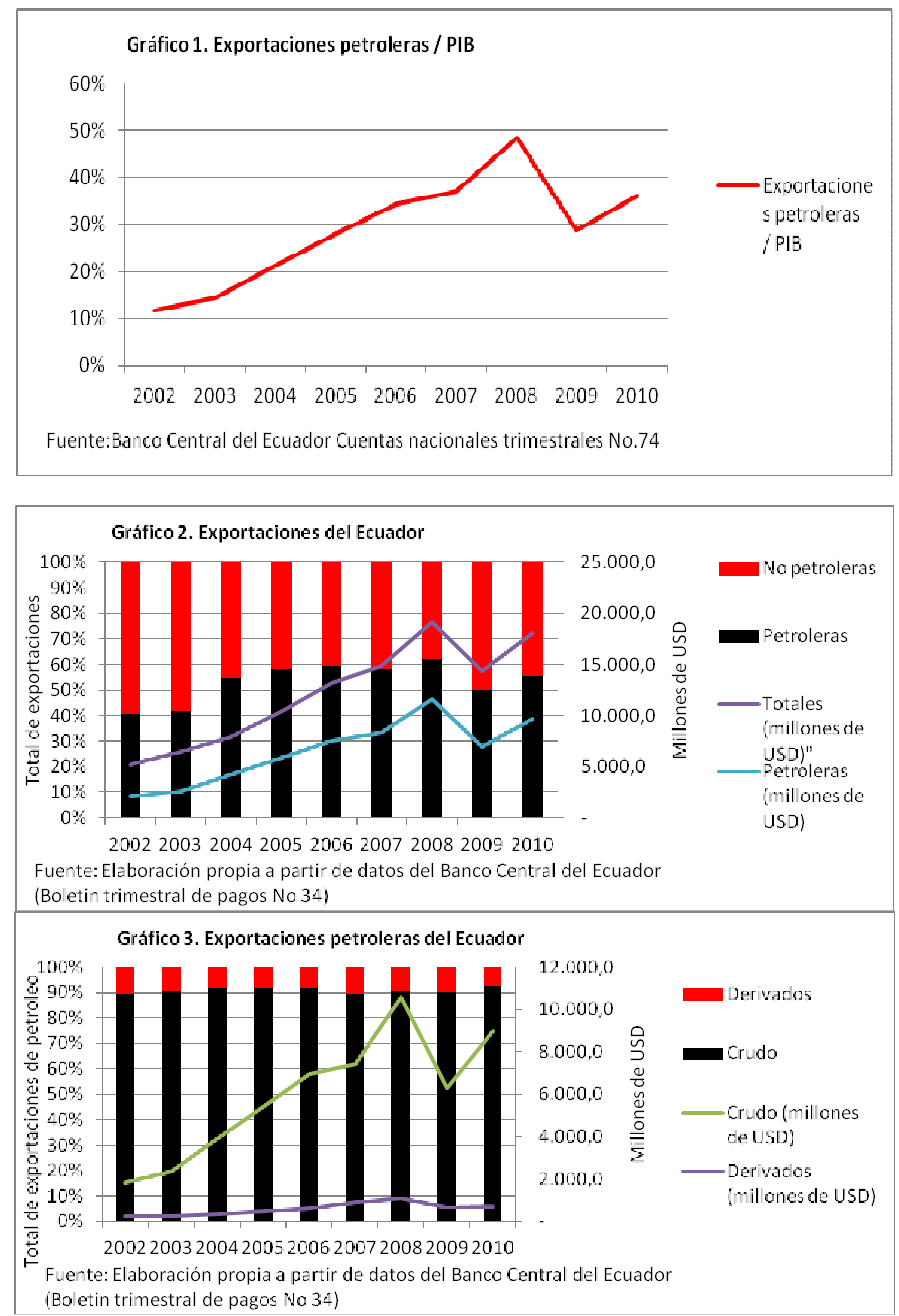

Dado que medidas en barriles las exportaciones de petróleo muestran una tendencia estancada a partir del 2004 y descendente a partir del 2006, lo que influye en el aumento de su peso relativo en las exportaciones totales es la evolución del precio

Papeles de Europa 
Bäckström, Caroline. Evolución y tendencias del rentismo petrolero en el ecuador 2001-2010.

de petróleo. Así, el valor de las exportaciones de petróleo evoluciona de forma similar al precio de petróleo, sobre todo a partir del 2004 (Gráfico 4). El porcentaje de la producción petrolera total que se destina a la exportación aumentó durante todo el periodo analizado sin que hubiera ningún punto de inflexión en el 2007. Así, en el 2001 el 54\% de la producción petrolera fue exportado, mientras que en el 2009 esta cifra fue de $64 \%{ }^{6}$.

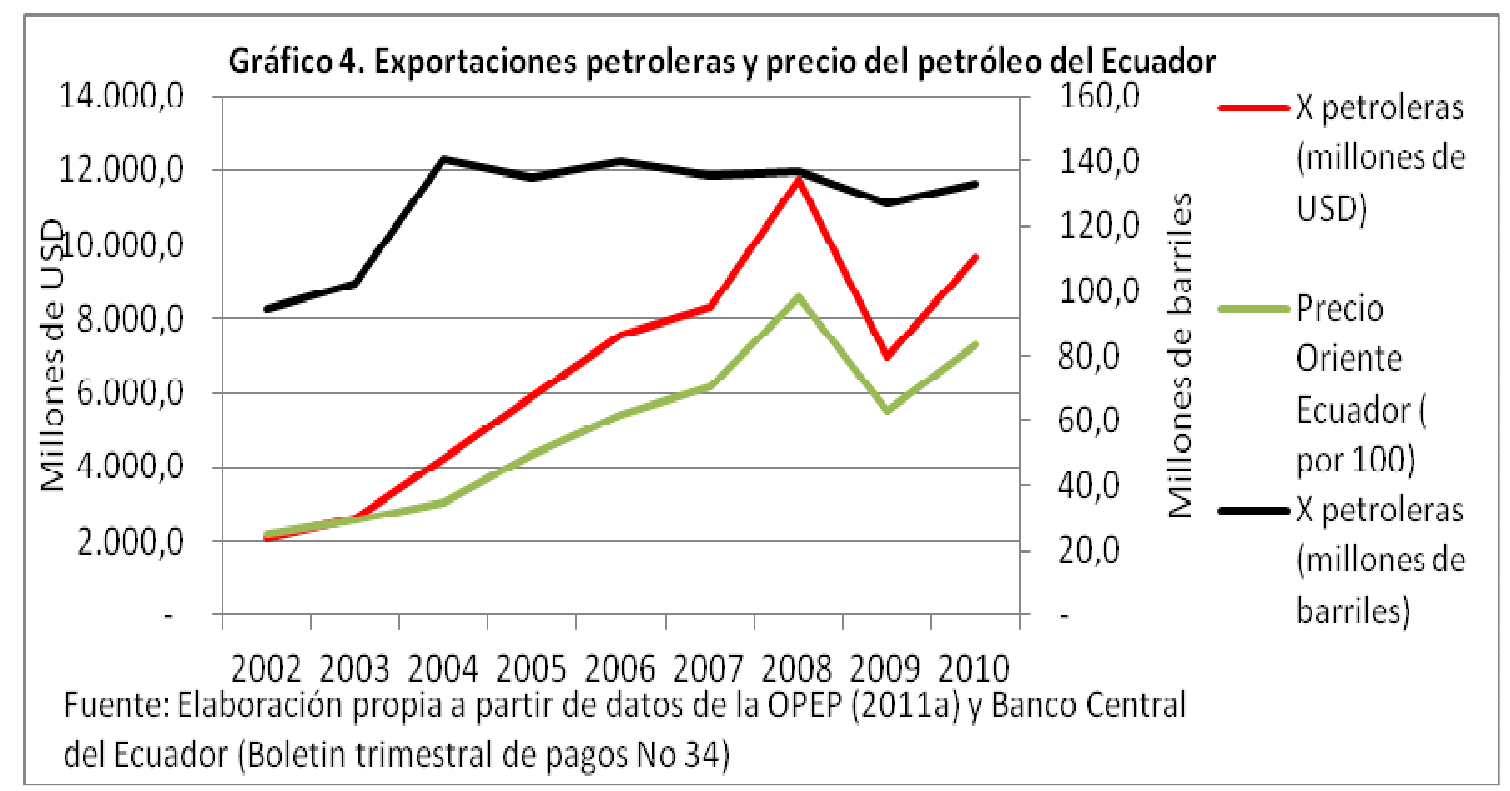

\subsubsection{El sector de petróleo y la estructura sectorial de la economía}

La economía ecuatoriana se puede considerar poco diversificada dado que son cinco los sectores con un peso mayor al $10 \%$ en el PIB y juntos representaron en el 2010 el 64\% del PIB. De estos, los tres sectores más grandes (comercio, otros servicios $^{7}$ y sector petrolero) representaron el mismo año el $44 \%$ del PIB. Esta distribución sectorial del PIB se mantuvo a lo largo del periodo analizado. (Gráfico 5) El grado de diversificación de la economía es un criterio importante a la hora de clasificar un país como rentista. Así, Noruega e Indonesia (países exportadoras de petróleo) no son consideradas rentistas por contar con economías diversificadas (Mañe Estrada y Cámara Arilla, 2004).

El peso del sector petrolero en una economía rentista petrolera debe ser alto. El sector petrolero ecuatoriano perdió peso en el PIB durante este periodo, pasando de un $16 \%$ a un $13 \%$ y pesando como máximo en el 2004 y 2005 un $18 \%$ del PIB. En el caso de Ecuador, el sector no llega a tener la misma importancia como en Kuwait, país rentista por excelencia, donde el sector representa alrededor de 30-40\% (Mañé Estrada y de la Cámara Arilla, 2004). Sin embargo, el sector petrolero de Venezuela, país que también es considerado rentista, representó un $12 \%$ del PIB en el $2010^{8}$ y niveles similares se encuentran en Noruega e Indonesia, países que no se consideran rentistas. Esto nos indica que este criterio, aunque necesario, no es

\footnotetext{
${ }^{6}$ Cálculos propios a partir de datos de: Banco Central del Ecuador-Boletín Anuario No. 32, International Energy Agency y OPEP(2011a)

${ }^{7}$ Otros servicios incluye: hoteles, bares y restaurantes; comunicaciones; alquiler de vivienda; servicios a las empresas y a los hogares, educación y salud.

${ }^{8}$ Fuente: Banco Central de Venezuela
} 
Bäckström, Caroline. Evolución y tendencias del rentismo petrolero en el ecuador 2001-2010.

suficiente para caracterizar una economía como rentista. Así, el sector petrolero ecuatoriano no tiene el mismo peso que los países rentistas por excelencia, sin embargo el petróleo es importante para la economía del país ya que es el segundo sector más importante después de los servicios. (Tabla 1).

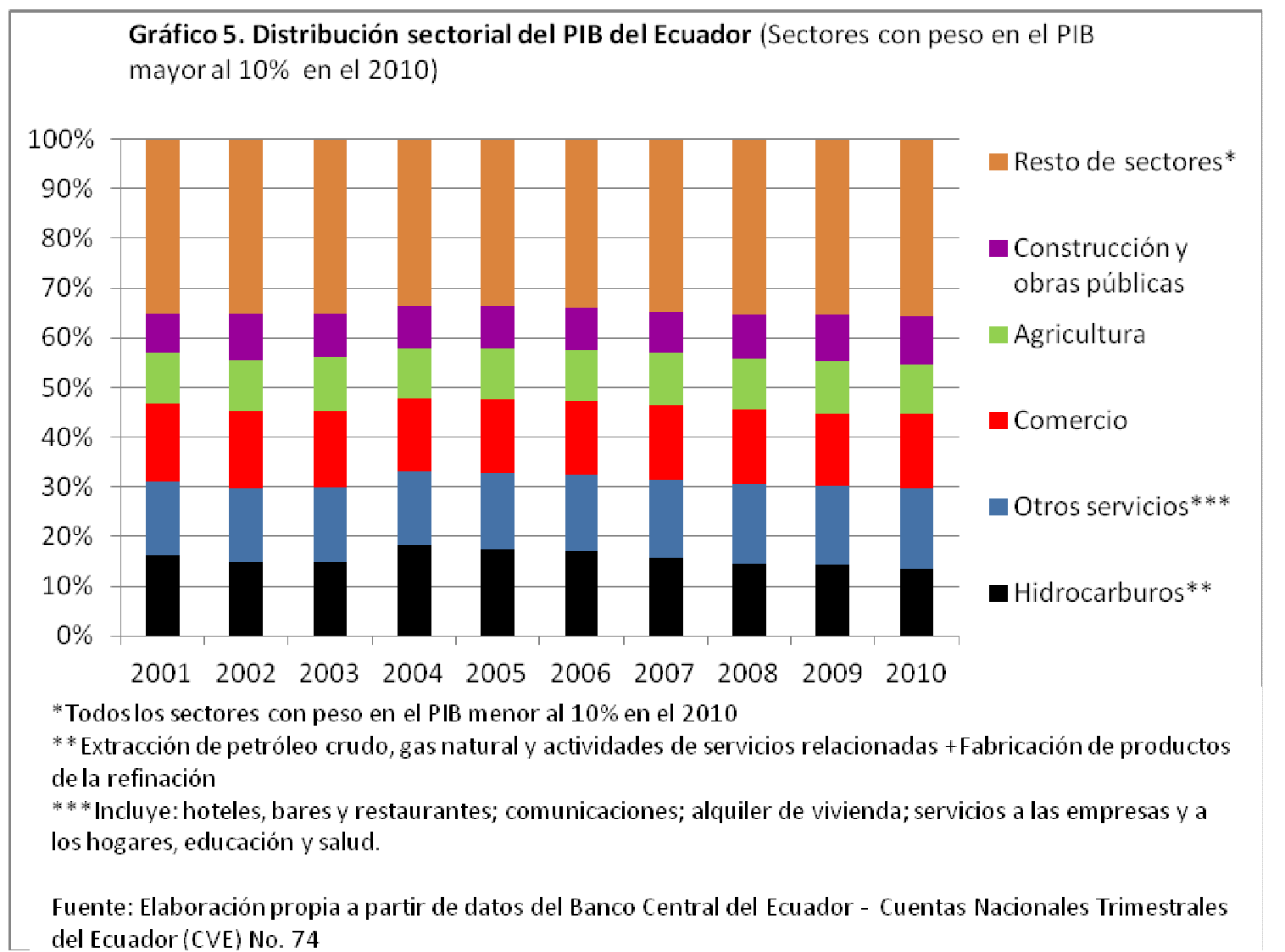

Tabla1. Distribución sectorial del PIB (\% del PIB, por orden de importancia en el 2010)

\begin{tabular}{|lcccccccccc|}
\hline & $\mathbf{2 0 0 1}$ & $\mathbf{2 0 0 2}$ & $\mathbf{2 0 0 3}$ & $\mathbf{2 0 0 4}$ & $\mathbf{2 0 0 5}$ & $\mathbf{2 0 0 6}$ & $\mathbf{2 0 0 7}$ & $\mathbf{2 0 0 8}$ & $\mathbf{2 0 0 9}$ & $\mathbf{2 0 1 0}$ \\
\hline 1. Servicios & 53 & 53 & 53 & 50 & 51 & 51 & 51 & 52 & 53 & 53 \\
\hline 2. Hidrocarburos & 16 & 15 & 15 & 18 & 18 & 17 & 16 & 15 & 14 & 13 \\
\hline 3.Agricultura & 10 & 10 & 11 & 10 & 10 & 10 & 10 & 10 & 10 & 10 \\
\hline $\begin{array}{l}\text { 4. Otros elementos del } \\
\text { PIB }\end{array}$ & 8 & 9 & 8 & 8 & 8 & 8 & 9 & 9 & 9 & 9 \\
\hline $\begin{array}{l}\text { 5. Elaboración de } \\
\text { alimentos y bebidas }\end{array}$ & 7 & 7 & 7 & 7 & 7 & 7 & 8 & 8 & 8 & 8 \\
\hline 6. Manufacturas & 7 & 7 & 7 & 6 & 6 & 6 & 6 & 6 & 6 & 6 \\
\hline Total PIB & 100 & 100 & 100 & 100 & 100 & 100 & 100 & 100 & 100 & 100 \\
\hline $\begin{array}{l}\text { Fuente: Elaboración propia a partir del Banco Central del Ecuador - Cuentas Nacionales Trimestrales del Ecuador } \\
\text { (CVE) No. 74 }\end{array}$
\end{tabular}

El hecho de que el sector petrolero perdió peso en el PIB a partir del 2004, a pesar del fuerte crecimiento del precio de petróleo, refleja que el nivel de producción de petróleo tuvo dificultades de mantenerse. Así, la producción de petróleo por barriles diarios estuvo estancada entre 2004 y 2006 y entre 2006-2010 cayó, contribuyendo a la pérdida de peso del sector petrolero en el PIB (Gráfico 6). Así, la pérdida de 
Bäckström, Caroline. Evolución y tendencias del rentismo petrolero en el ecuador 2001-2010.

peso del sector en el PIB a partir del 2004, combinado con la tendencia descendiente de la producción petrolera después del 2006, se pueden indicar que el sector carece de dinamismo en la segunda mitad del periodo analizado. La subida del precio del petróleo atenúa parcialmente este hecho, aunque implica que la economía ecuatoriana se vuelve más dependiente y vulnerable ante las fluctuaciones del mismo ya que una producción decreciente necesita de altos precios de petrolero para mantener el mismo nivel de valor añadido. Esta dependencia será analizada con mayor detalle más adelante. La disminución de la producción se debe al proceso de renegociación de los contratos petroleros introducidos por el Gobierno de AP, que en enero del 2007 aumentó el impuesto a las ganancias extraordinarias de las empresas extranjeras de un $50 \%$ a un $99 \%$, cuestión que provocó que las empresas extranjeras redujeran su actividad petrolera en el país. De esta manera la producción petrolera de estas empresas cayó de 255 700 barriles por día a 162 000, siendo esto una brecha que equivale a 2,3 mil millones de dólares y equivalente a un 4\% del PIB (The Economist, 2010).

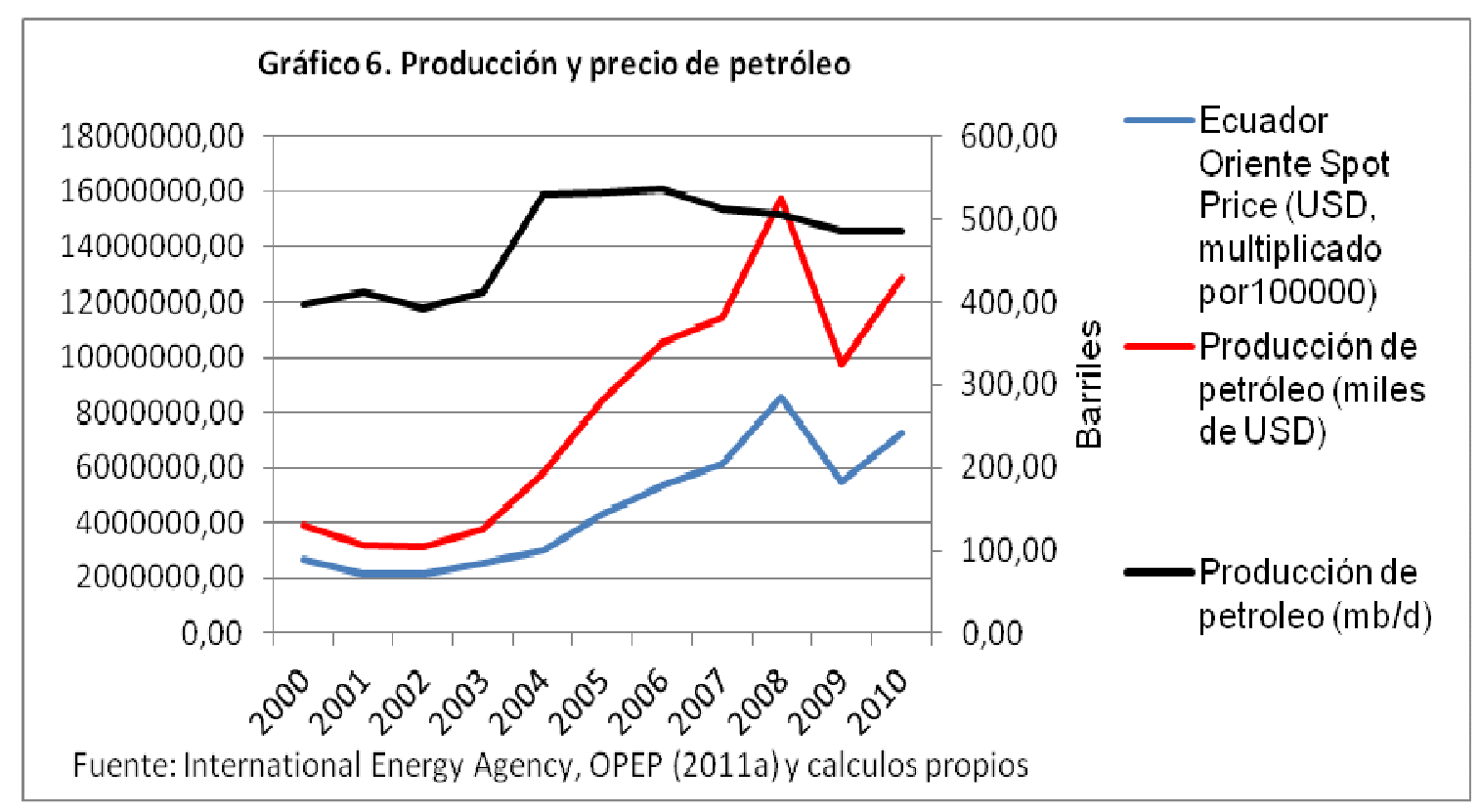

\subsubsection{La evolución de los sectores no petroleros}

La caída del peso del sector de petróleo se contrarresta principalmente por un aumento del peso del sector servicios, pero también por el aumento de la producción de alimentos y bebidas y otros elementos del $\mathrm{PIB}^{9}$. La agricultura mantuvo su peso a lo largo del periodo y las manufacturas disminuyeron levemente (Gráfico 7). Las tres ramas más grandes del sector de servicios (otros servicios, comercio y construcción y obras públicas) fueron las que más crecieron en valores absolutos entre 20012010. A partir del 2007, crece de forma acentuada el sector de la construcción y obras públicas, de acuerdo con las grandes inversiones realizadas por el Gobierno de AP, cuestión que se analiza más adelante en el trabajo. También el comercio aumenta más a partir del 2007. (Gráfico 7)

\footnotetext{
${ }^{9}$ Otros elementos del PIB incluye diversos impuestos y subsidios 
Bäckström, Caroline. Evolución y tendencias del rentismo petrolero en el ecuador 2001-2010.

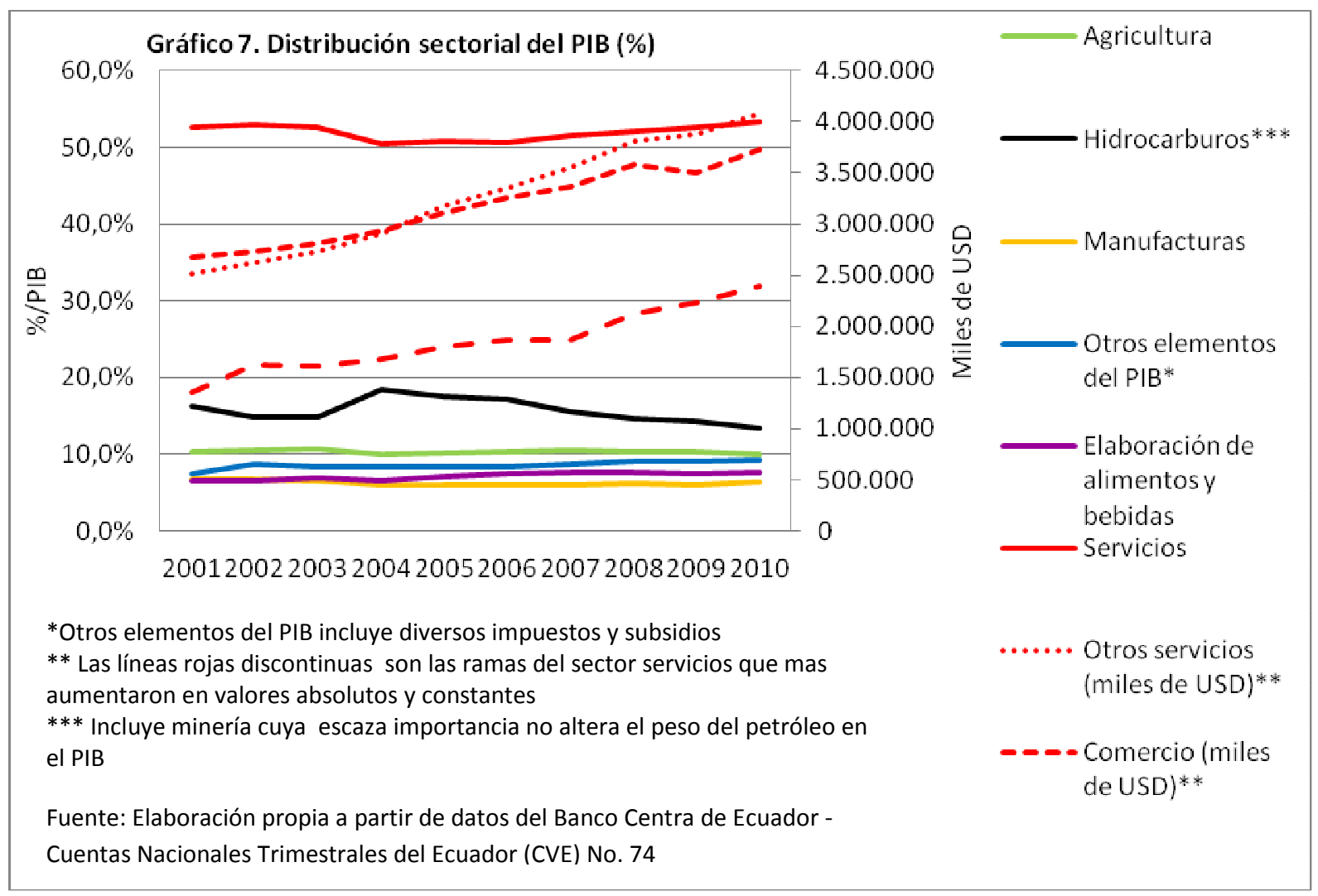

\begin{tabular}{|c|c|c|c|c|c|c|c|c|c|c|}
\hline & 2002 & 2003 & 2004 & 2005 & 2006 & 2007 & 2008 & 2009 & 2010 & $\begin{array}{l}\text { Aumento } \\
2007-2010\end{array}$ \\
\hline Total & 6.160 & 6.366 & 7.684 & 9.709 & 11.408 & 13.047 & 17.912 & 14.268 & 19.641 & $51 \%$ \\
\hline Bienes de consumo & 1.739 & 1.791 & 2.069 & 2.354 & 2.598 & 2.924 & 4.037 & 3.119 & 4.306 & $47 \%$ \\
\hline No duraderos & 908 & 1.008 & 1.189 & 1.339 & 1.494 & 1.794 & 2.355 & 1.892 & 2.248 & $25 \%$ \\
\hline Duraderos & 831 & 783 & 880 & 1.015 & 1.105 & 1.130 & 1.683 & 1.227 & 2.058 & $82 \%$ \\
\hline Combustibles y lubricantes & 232 & 733 & 995 & 1.715 & 2.381 & 2.578 & 3.358 & 2.338 & 4.043 & $57 \%$ \\
\hline Materia primas & 2.113 & 2.028 & 2.566 & 2.935 & 3.469 & 4.093 & 5.828 & 4.670 & 5.915 & $44 \%$ \\
\hline Bienes de capital & 1.920 & 1.703 & 1.944 & 2.557 & 2.829 & 3.319 & 4.501 & 3.927 & 5.129 & $55 \%$ \\
\hline
\end{tabular}

Hemos visto que el comercio es una de las ramas de servicios más importantes y el que más se expandió durante el periodo analizado. El comercio necesita de importaciones debido a la limitada capacidad del sector manufacturero de producir bienes de consumo de forma competitiva. También la construcción y obras públicas necesitan importar, en este caso bienes de capital. Se trata sobre todo de las importaciones de bienes de capital que se financian con ingresos petroleros a través de las inversiones en obras públicas realizados por el gobierno. Así, como se puede ver en el gráfico inferior, las importaciones crecieron fuertemente durante todo el periodo, aunque a partir del 2007 de forma más acentuada. Así el valor de las importaciones pasó de unos 6200 millones de USD en el 2002 a 19600 millones en el 2010 (Gráfico 8). Las que más aumentaron entre 2007-2010 fueron las 
Bäckström, Caroline. Evolución y tendencias del rentismo petrolero en el ecuador 2001-2010.

importaciones de bienes de consumo duraderos, que aumentaron su valor entre esos años en un $82 \%$. También crecieron las importaciones de combustibles y lubricantes (57\%) y bienes de capital (55\%) (Tabla 2$)$.

El fuerte aumento de las importaciones de combustibles y lubricantes refleja la poca capacidad de refinamiento de petróleo del país y las importaciones de bienes de consumo y bienes de capital va de acuerdo con el crecimiento del comercio y la construcción. La necesidad de importar no sólo viene dada por la falta de capacidad de producción del país, sino también por un bajo nivel de competitividad de los productos domésticos en relación a los provenientes de otros países. El creciente sector de comercio significa un problema para el sector exterior de la economía ecuatoriana, ya que depende de un volumen de importaciones cada vez mayor, que a su vez afecta de forma negativa a la balanza comercial. Así, la balanza comercial registró un saldo negativo de 1580 millones de USD en el 2010.

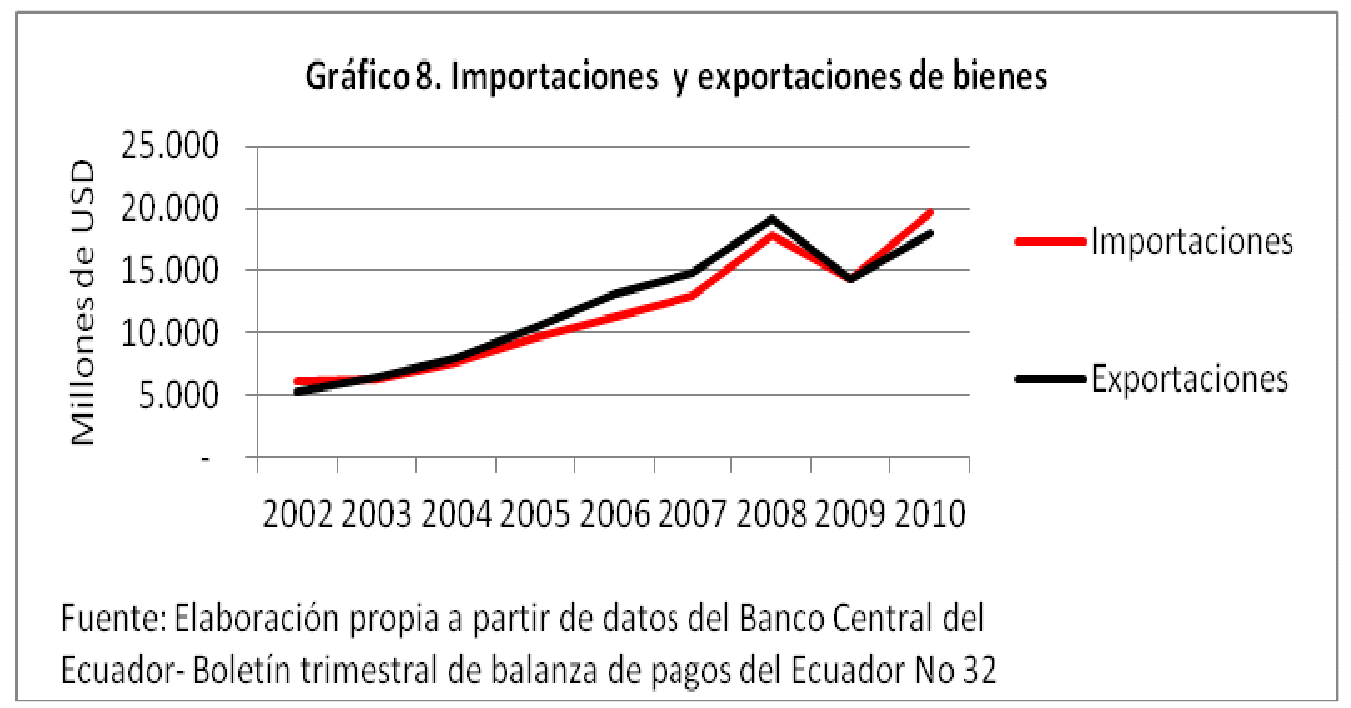

La minería ${ }^{10}$ sólo empleó en el 2009 un 0,5\% de la población ocupada urbana, nivel que se mantuvo más o menos constante durante el periodo analizado (Anexo, Tabla 3). Teniendo en cuenta su peso en el PIB de 13-18\%, se entiende que se trata de un sector intensivo en capital, poco intensivo en trabajo y altamente productivo. En contraste, el sector de servicios empleó en el 2009 el 78,8\% del total de la población ocupada urbana lo cual significó un aumento con 3,7\% comparado con 2001 (Tabla 3).

Dentro de los servicios fue la rama de comercio la que más población empleó, con valores constantes alrededor del $30 \%$ del total de la población ocupada urbana a lo largo del periodo analizado (Comisión Económica para América Latina). Así, a pesar de que el comercio gana peso en el PIB y crece fuertemente en valores absolutos, no aumenta su importancia en términos de empleo. El sector manufacturero es el que más población ocupa después de los servicios, aunque tuvo una tendencia descendente entre 2001-2009. Así, en el 2001, las manufacturas emplearon un $16,4 \%$ y en el 2009 un 13,1\% (Tabla 3). Esto no significa que exista un sector

\footnotetext{
10 Para la presentación de la ocupación por ramas de actividad económica la CEPAL utiliza las grandes divisiones de la Clasificación Industrial Internacional Uniforme de todas las actividades económicas, Rev.2 (CIIU) de las Naciones Unidas, en el cual en la minería se incluye el sector petrolero. ( CEPAL-Ficha técnica de empleo y Naciones Unidas, 2009) Además, en el caso de Ecuador la actividad petrolero domina eneste sector.
} 
Bäckström, Caroline. Evolución y tendencias del rentismo petrolero en el ecuador 2001-2010.

manufacturero importante, ya que como nos confirman la tabla 1 y en el gráfico 7, el peso del sector manufacturero en el PIB es relativamente reducido, por lo cual está más bien relacionado con que es un sector intensivo en trabajo y de baja productividad. En general, no existe ningún cambio significativo en la distribución del empleo a lo largo del periodo, excepto un leve aumento de la población empleada en servicios contrarrestado por la disminución de la población empleada en manufacturas.

\begin{tabular}{|lccccccccc|}
\hline \multicolumn{1}{|c|}{ Tabla 3. Estructura de la población ocupada urbana total por sectores (\% del total } \\
de la población ocupada urbana) \\
\hline & $\mathbf{2 0 0 1}$ & $\mathbf{2 0 0 2}$ & $\mathbf{2 0 0 3}$ & $\mathbf{2 0 0 4}$ & $\mathbf{2 0 0 5}$ & $\mathbf{2 0 0 6}$ & $\mathbf{2 0 0 7}$ & $\mathbf{2 0 0 8}$ & $\mathbf{2 0 0 9}$ \\
\hline Servicios* & 75,1 & 76,3 & 76,6 & 77,3 & 77,6 & 77,7 & 78,9 & 78,1 & 78,8 \\
\hline Manufacturas & 16,4 & 14,5 & 13,8 & 14,6 & 13,8 & 13,8 & 13,2 & 13,7 & 13,1 \\
\hline Agricultura & 7,5 & 8,5 & 9,1 & 7,6 & 8,3 & 8,2 & 7,4 & 7,8 & 7,6 \\
\hline Minería & 0,5 & 0,6 & 0,6 & 0,5 & 0,3 & 0,4 & 0,4 & 0,5 & 0,5 \\
\hline $\begin{array}{l}\text { * Incluye: servicios financieros, transporte, comercio, construcción, electricidad, gas y agua y } \\
\text { otros servicios } \\
\text { Fuente: CEPALSTAT }\end{array}$
\end{tabular}

\subsubsection{Distribución privado-pública del sector petrolero}

En cuanto a la distribución privado-pública del sector petrolero, ésta evolucionó a favor del sector público a finales del periodo analizado, tanto en cuanto a producción como a exportaciones y renta petrolera.

En enero del 2007 la producción petrolera pública representó el 51\% y un 49\% la privada, mientras que en diciembre de 2010 fueron de $69 \%$ y $29 \%$ respectivamente. Las exportaciones se redistribuyeron a favor del sector público de forma aún más acentuada. Así, en enero de 2007 el 55\% de las exportaciones petroleras totales fueron públicas mientras que en diciembre de 2010 alcanzaron el 81\% (Tabla 4).

Como se aprecia en el gráfico 9, la renta petrolera se distribuyó a favor de las empresas extranjeras entre 2001-2005. Durante este periodo la renta petrolera por barril, medido en valores absolutos, fue creciendo tanto para Petroecuador como para las empresas extranjeras, debido a la alza del precio de petrolero. En este periodo el coste de producción de Petroecuador fue inferior al de las empresas extranjeras, debido a la escasa reinversión realizada por la empresa estatal mientras que les pasaba lo contrario a las empresas extranjeras. Por esta razón la renta por barril de Petroecuador fue superior a la de las empresas extranjeras en todos los años entre 2001-2005. Sin embargo, debido al aumento de la producción de las empresas privadas y el deterioro de la producción de Petroecuador, durante estos años la distribución de la renta petrolera total cambió notablemente a favor de las empresas extranjeras. Así, a partir de 2004, la renta petrolera de las empresas extranjeras es mayor a la de Petroecuador (Tabla 5 y CEPAL, 2008). Sin embargo, en el 2010 Petroecuador vuelve a tener la mayor parte de la renta petrolera a pesar de un mayor coste de producción y una menor renta por barril que la de las empresas extranjeras. Lo que entonces determina el alto nivel de renta petrolera de Petroecuador es que duplica la producción en barriles comparado con 2005. El alto coste de producción de la empresa pública en el 2010 se debe a que Petroecuador 
Bäckström, Caroline. Evolución y tendencias del rentismo petrolero en el ecuador 2001-2010.

realizó inversiones de 1700 millones de USD. Así, si no se toman en cuenta las inversiones realizadas por Petroecuador en el 2010, la renta petrolera asciende a un 7570 millones de USD, comparado con 5840 millones de USD. En valores absolutos, la renta petrolera del sector público se dispara a partir del 2005 mientras que la de las empresas extranjeras disminuye levemente. Resulta evidente la redistribución de la renta petrolera a favor del sector público con la llegada del Gobierno de AP (Tabla 5 y Gráfico 9).

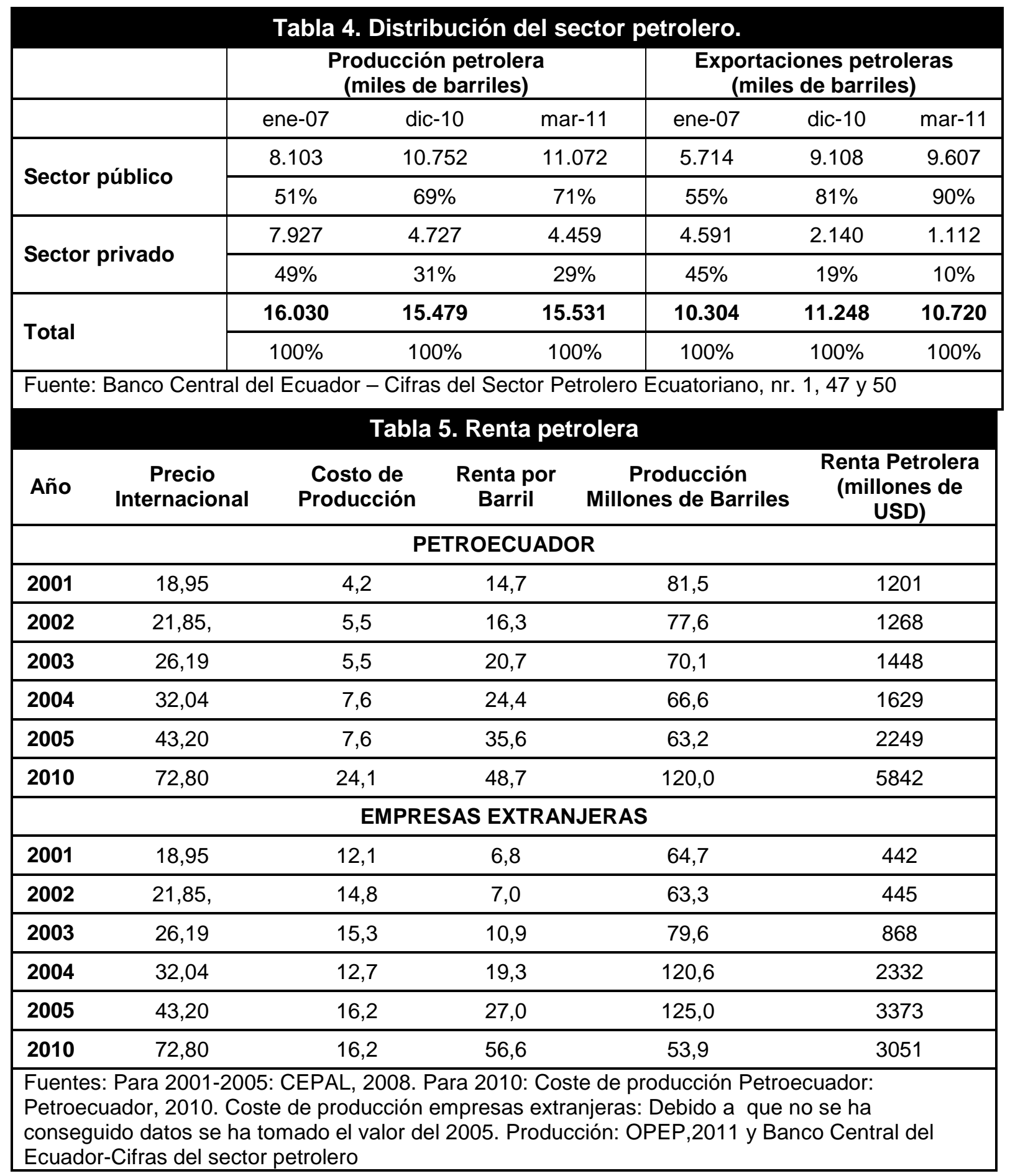


Bäckström, Caroline. Evolución y tendencias del rentismo petrolero en el ecuador 2001-2010.

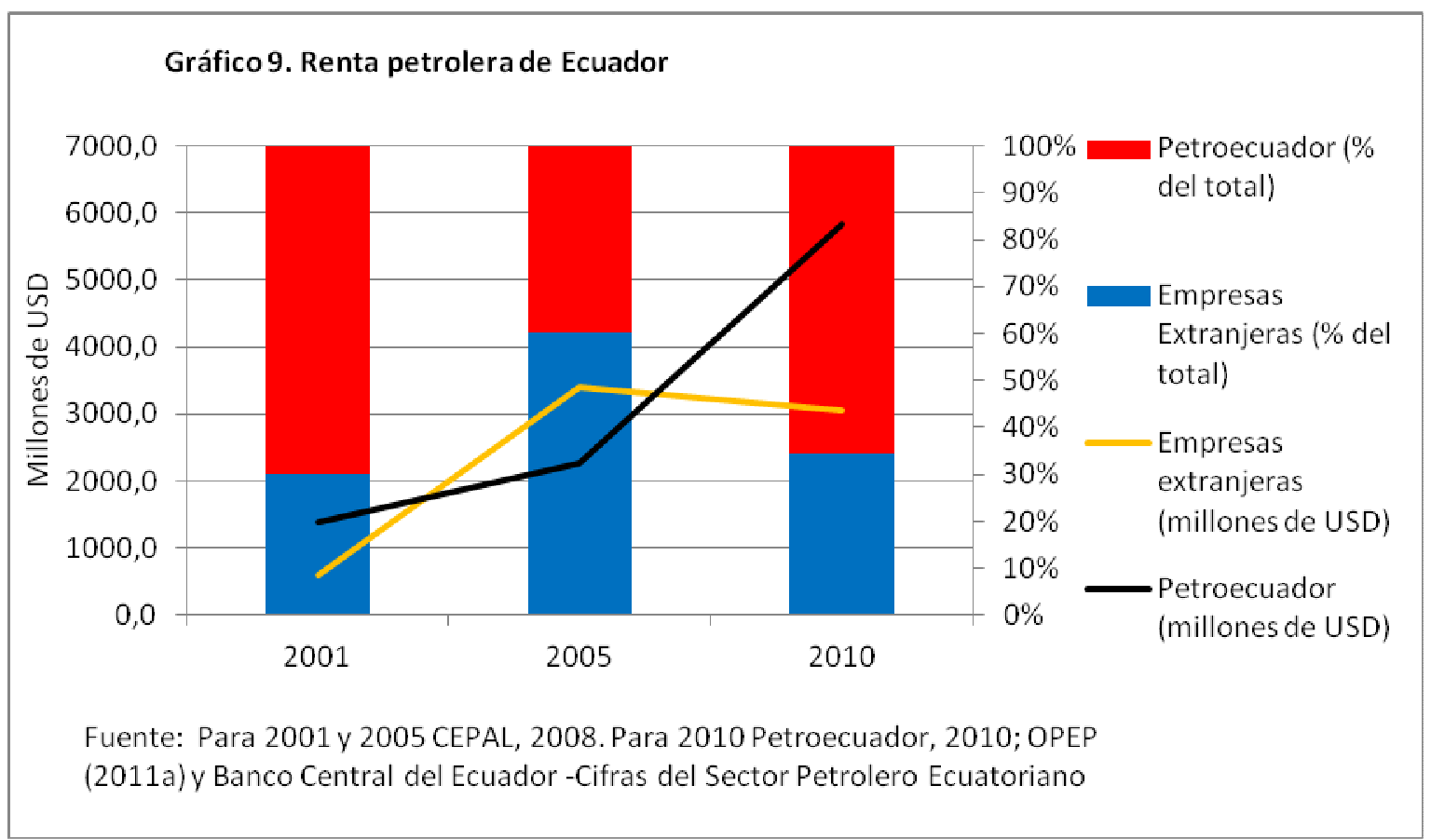

En un estudio realizado por Bank of América, se destaca que el modelo de contrato de Prestación de Servicios introducido por el Gobierno de AP es el único en el mundo que beneficia al Estado en la renta cuando el precio del petróleo pasa los 78 dólares. Así, la participación estatal en la renta petrolera sube junto con el precio de petróleo ya que cuando el barril de petróleo cuesta 80 dólares, la participación del Estado en la renta petrolera es de $79 \%$ y cuando el precio de petrolero es de 100 dólares, esta sube a $86 \%$. Tras la renegociación de los contratos del 2010, Ecuador se convirtió en uno de los países con mayor participación en la renta petrolera después de Libia, Rusia, Angola y Nigeria. Pero la mayor participación se logró ya con los contratos transitorios en el proceso de cambio de modelo (Allison, 2011).

Así, la redistribución del sector entre el sector público y privado se explica por el proceso de renegociación de los contratos petroleros, introducidas por el Gobierno de Rafael Correa. Con este cambio en el marco jurídico del sector se buscó aumentar la participación del Estado en la renta petrolera, objetivo que estuvo previsto ya en el Plan de Gobierno de AP, elaborado en el 2006. Durante el gobierno de Alfredo Palacios, se emitió una la ley reformatoria de la Ley de Hidrocarburos del 1978, que obligó a las empresas extranjeras a entregar el 50\% de las ganancias extraordinarias de las ventas de petróleo al Estado, quedándose las empresas con el otro $50 \%$. Posteriormente, en octubre de 2007, el Gobierno de AP, descontento con esto, realizó una modificación en esta ley, estableciendo que el $99 \%$ de las ganancias extraordinarias irían al Estado y sólo el 1\% se quedaría en las compañías privadas. Esto dio lugar a protestas por parte de las empresas extranjeras, lo cual resultó en que en el 2008 se firmaran acuerdos de modificaciones contractuales transitorias por uno o dos años. En julio de 2010 entró en vigor la Ley Reformatoria de la Ley de Hidrocarburos y de Régimen Tributario Interno en la que se abrió la puerta para la introducción de cambio de modalidad de los contratos de participación a contratos de prestación de servicios. A partir de entonces empezaron las renegociaciones con las empresas petroleras, que culminaron unos meses más 
tarde con el acuerdo con cinco empresas extranjeras ${ }^{11}$. Éstas, ubicadas en los campos más importantes, se pasaron de contratos de participación a contratos de prestación de servicios. Cuatro empresas ${ }^{12}$ no llegaron a un acuerdo con el Estado y las actividades de estas empresas fueron asumidas por las empresas públicas o, en caso de falta de capacidad de estás, licitadas. Según la nueva modalidad de prestación de servicios, el total de la extracción de crudo pertenece al gobierno y a las empresas se les paga una tarifa fija por barril extraído. Si las empresas extranjeras quisieran aumentar sus utilidades, lo pueden hacer reduciendo costos, lo cual provocaría un incremento del impuesto a la renta para el Estado, ya que las empresas extranjeras pagan un mínimo de $25 \%$ de impuesto a la renta. Si la empresa produce más de lo previsto, el Estado recibe $80 \%$ del beneficio y la empresa el $20 \%$ de acuerdo con la distribución de la renta petrolera establecida oficialmente. Además, el Estado asume el coste del transporte del petróleo a través del Oleoducto de Crudos Pesados (OCP) (Acosta, 2011).

\subsection{Objetivos de la gestión del sector petrolero y fiscalidad petrolera}

\subsubsection{La reforma del sector petrolero ecuatoriano}

En septiembre de 2008 se aprobó por mayoría de la población ecuatoriana un nuevo marco constitucional. Esta nueva constitución demandó y demanda importantes cambios en el marco jurídico del sector de hidrocarburos. Se redefine el papel del Estado en la explotación de recursos naturales no renovables y se reclama el fortalecimiento del Estado y de sus empresas, significando esto un cambio radical al modelo anterior (Acosta, 2011). Esto está en línea con el Plan Nacional de Desarrollo, que reclama la redefinición del papel del Estado a través del objetivo 12, que establece que es necesario reformar el Estado para el bienestar colectivo. "Centrada en un conjunto de reformas institucionales y mejoras políticas, económicas y sociales, la nueva visión de desarrollo del Ecuador entiende que el Estado es actor fundamental del cambio, garante de un funcionamiento adecuado del mercado y de la corrección de su funcionamiento, pero sobre todo debe asegurar, de manera universal, un conjunto de servicios básicos y derechos fundamentales de las personas." (República del Ecuador, 2007a, p.276). Así, el Estado debe ser el centro de la reforma institucional para recuperar su papel estratégico y su capacidad de regulación y redistribución. Uno de los aspectos claves para el presente análisis es que en esta nueva visión de desarrollo, la ganancia extraordinaria, al no reflejar los costes reales de producción, debe ser regulada para su correcta redistribución social y canalización hacia la reactivación de sectores productivos y sensibles de la economía. Se establece que es necesario invertir en los servicios públicos, ya que benefician a la mayoría de la población, y que el Estado es el responsable de proveer estos servicios de forma eficiente. También se constata la importancia de la recuperación y el aumento de la competitividad de las empresas públicas. (República del Ecuador, 2007a) La Visión de Hidrocarburos establece que para el nuevo modelo de desarrollo del Estado ecuatoriano es esencial la recuperación de la soberanía y el incremento de los ingresos petroleros, ya que el sector de hidrocarburos es determinante para la

\footnotetext{
${ }^{11}$ Agip-Eni (Italia), Andes Petroleum (China), Petroriental (China), Repsol-YPF (hispano-argentina) Enap-Sipec (Chile)

${ }_{12}$ Petrobras (Brasil), Energy Development Corporation -EDC (Estado Unidos), Cánada Grande (Corea), National Petrolerum Corporation - CNPC (China)
} 
Bäckström, Caroline. Evolución y tendencias del rentismo petrolero en el ecuador 2001-2010.

economía del país. Las nuevas políticas de soberanía del crudo respaldan el hecho de que el petróleo sea $100 \%$ ecuatoriano y la nueva Ley de Hidrocarburos es la herramienta que propicia esta nueva visión. Así, uno de los principios fundamentales de la Constitución Política del Ecuador, que también figura en los objetivos de desarrollo del Plan Nacional del Buen Vivir, es la promoción del aprovechamiento sustentable y soberano del petróleo, gas y derivados y la distribución equitativa y justa de su riqueza (Ministerio de Recursos No Renovables del Ecuador, 2009).

Ya que la constitución del 2008 establece que el manejo de los recursos petroleros es de competencia exclusiva del Estado y que son considerados estratégicos, la construcción de su organización institucional es fundamental. Así, la constitución también establece que el Estado tiene la potestad de crear empresas públicas para la gestión de recursos estratégicos. La empresa nacional petrolera está encargada de la producción y comercialización del petróleo. A principios del 2007 Petroecuador empezó un proceso de reestructuración, después de haber sido declarada en estado de emergencia por el nuevo gobierno. El objetivo de éste fue otorgarle autonomía, por lo cual en el nuevo esquema de funcionamiento, aprobado en el 2010, desaparecieron las filiales y se crearon seis gerencias de acuerdo a la cadena de valor del petróleo ${ }^{13}$. Así, se reincorporan todas las funciones en una sola empresa y se crea de esta manera la nueva empresa pública de petróleo, Petroecuador EP. (Ordoñez, Pantoja y López, 2010) La reforma de la ley de hidrocarburos busca un mayor control y participación del Estado en el sector, además de "impulsar la actividad hidrocarburífera incrementando los niveles de producción de los campos petroleros, dentro de un esquema contractual de prestación de servicios, que devuelva la titularidad de la totalidad de la producción nacional a favor del Estado, estableciendo únicamente el reconocimiento de una tarifa por barril producido a favor de las Contratistas, que no fluctué en función del precio de petróleo, del cual se han beneficiado desproporcionadamente las compañías operadoras" (República del Ecuador, 2010, p.1) Así, en la nueva Ley de Hidrocarburos, el Estado explorará y explotará el petróleo directamente a través de Petroecuador EP y sólo de manera excepcional puede delegar que estas actividades sean realizadas por empresas nacionales o extranjeras, por lo cual la Secretaria de Hidrocarburos puede firmar contratos de asociación, de participación, de prestación de servicios u otras formas contractuales que están en vigencia en la legislación. (República del Ecuador, 2010)

\subsubsection{Ingresos públicos y fiscalidad petrolera}

En el gráfico 10 se observa que los valores absolutos de los ingresos públicos totales crecieron durante todo el periodo y a partir del 2007 lo hicieron de manera más acentuada. Así, los ingresos petroleros del Gobierno de Rafael Correa fueron muy superiores a los de gobiernos anteriores ${ }^{14}$, alcanzando el valor de 17500 millones de dólares constantes entre 2007-2009. (Varela, 2010). Esto se debe principalmente al aumento de los ingresos petroleros dado por la mayor captación de la renta petrolera por parte del Estado, alcanzado por el Gobierno actual, combinado con el pico del precio de petróleo. Así, los ingresos públicos petroleros crecieron de forma moderada entre 2001-2007 y partir del 2007 de forma más acentuada.

\footnotetext{
13 Exploración y producción, transporte y almacenamiento, refinación, comercialización, seguridad-saludambiente y desarrollo organizacional.

${ }^{14}$ Ingresos petroleros por periodo de gobierno (millones de USD): Gustavo Noboa (2000-2002) 4700 , Lucio Gutiérrez (2002-2005) 6000 y Alfredo Palacio (2005-2007) 8200.
} 
Bäckström, Caroline. Evolución y tendencias del rentismo petrolero en el ecuador 2001-2010.

(Gráfico 10) Los datos del Gobierno Central - Base Caja nos ofrecen una desagregación entre ingresos tributarios y no tributarios de los ingresos petroleros. Aquí podemos ver que los ingresos petroleros tributarios tuvieron una importancia mínima, del 3-1\% entre 2001-2006, y en el 2008 y 2009 es nula. ${ }^{15}$ Esto resulta incomprensible dado que el impuesto sobre las ganancias extraordinarias de las empresas petroleras extranjeras pasó del $50 \%$ al $99 \%$ en enero del 2007 , y que el proceso de migración de las empresas extranjeras a contratos de prestación de servicios no concluyó hasta finales del 2010. Además, estos nuevos contratos no significan que se deja de cobrar impuestos a las empresas petroleras extranjeras, ya que según la nueva Ley de Hidrocarburos, se cobrará un mínimo de $25 \%$ de impuesto a la renta además de que las utilidades que éstas obtengan por la exploración y explotación estarán sujetas al 44,4\% de impuesto a la renta (República del Ecuador, 2010). De esta manera, se puede constatar que la laguna en los datos con respecto a los ingresos tributarios petroleros del 2008 y 2009 tiene que ver con la metodología utilizada para registrar estos ingresos en las cuentas públicas, y no con el hecho de que se elimine la presión fiscal sobre la actividad petrolera de las empresas extranjeras. Aunque, con la nueva ley de hidrocarburos, ésta sí disminuye de forma importante.

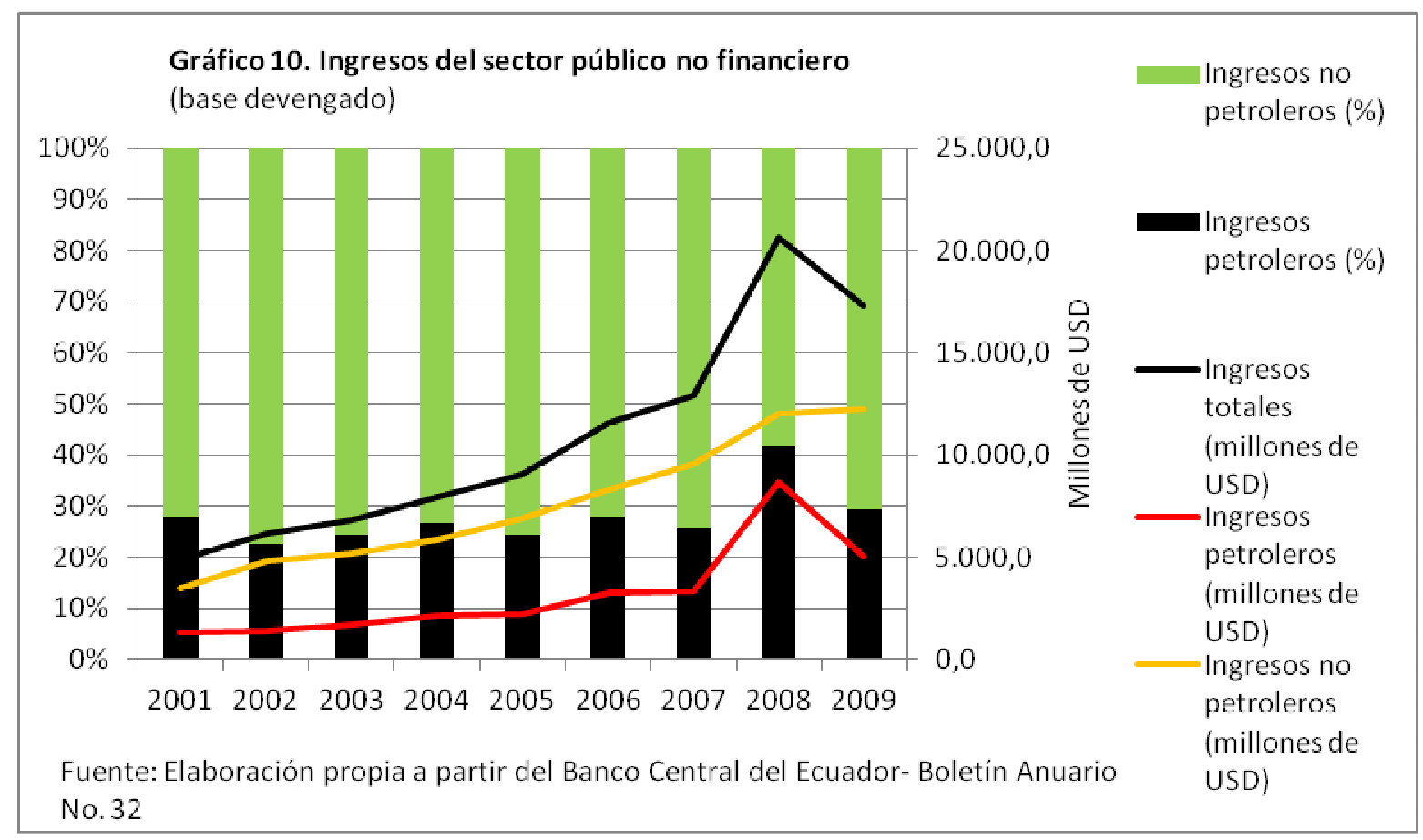

A pesar de mayores ingresos petroleros a partir del 2007, la fiscalidad petrolera ${ }^{16}$ del Sector Público no Financiero ${ }^{17}$ no cambió significativamente a lo largo del periodo, manteniéndose en un 28\% (2001) y 29\% (2009) con excepción del año del pico de petróleo en el que la fiscalidad petrolera alcanza un $42 \%$. Esto se debe a que el aumento de los ingresos no petroleros se mantiene después del 2008, cuando, en cambio, los ingresos petroleros caen. Sin embargo, a partir del 2007, también hay un punto de inflexión en el crecimiento de los ingresos no petroleros, aunque menos

\footnotetext{
${ }^{15}$ Fuente: BCE - Boletín Anuario No 32

${ }^{16}$ Peso de los ingresos fiscales petroleros en los ingresos fiscales totales

${ }^{17}$ Incluye Gobierno Central, Resto de Entidades del Sector Público y Empresas Públicas no Financieras (Fuente: Banco Central del Ecuador, Resumen Metodológico de Finanzas Públicas)
} 
Bäckström, Caroline. Evolución y tendencias del rentismo petrolero en el ecuador 2001-2010.

acentuado que el de los ingresos petroleros. En teoría, uno de los problemas que enfrenta un país rentista es que la renta petrolera es suficientemente significativa para que no haya necesidad de extraer recursos del resto de la economía a través de los ingresos tributarios, lo cual desincentiva las políticas dirigidas a promover la actividad económica nacional y el objetivo de la política económica es el gasto de la renta. Los ingresos no petroleros son los que mayor peso tienen en los ingresos fiscales del Ecuador y con excepción del 2008 mantuvieron un peso bastante constate alrededor del $70 \%$ de los ingresos totales. (Gráfico 10)

El Gobierno actual ha introducido medidas para aumentar los ingresos tributarios a través de la Ley Reformatoria para la Equidad Tributaria del 2007, que tiene como objetivo combatir la evasión y elusión en el pago de impuestos, además de incrementar la eficacia de la recaudación del Impuesto a la Renta de altos ingresos. (República del Ecuador, 2007a y Servicio de Rentas Internas, 2007) De esta manera, como se puede ver en el siguiente gráfico, los ingresos públicos tributarios no petroleros que más crecieron a partir del 2007 fueron los ingresos del impuesto sobre la renta. (Grafico 5) Sin embargo, el peso de los ingresos tributarios en los ingresos públicos está por debajo de su potencial y a pesar de que los ingresos petroleros son menos importantes que los tributarios, son de suma importancia comparado con otros países y han desincentivado la necesidad del Estado ecuatoriano de afianzar la recaudación tributaria. Así, en el 2005 el Ecuador fue el sexto país con menos presión tributaria de América Latina (CEPAL, 2007 y 2009). Esta cuestión se vuelve preocupante, dado que el peso de los ingresos tributarios disminuye de un $59 \%$ en el 2001 a un $51 \%$ en el 2009 , incluso a partir del 2007, a pesar el esfuerzo realizado por el gobierno de aumentarlos. (Grafico 11)

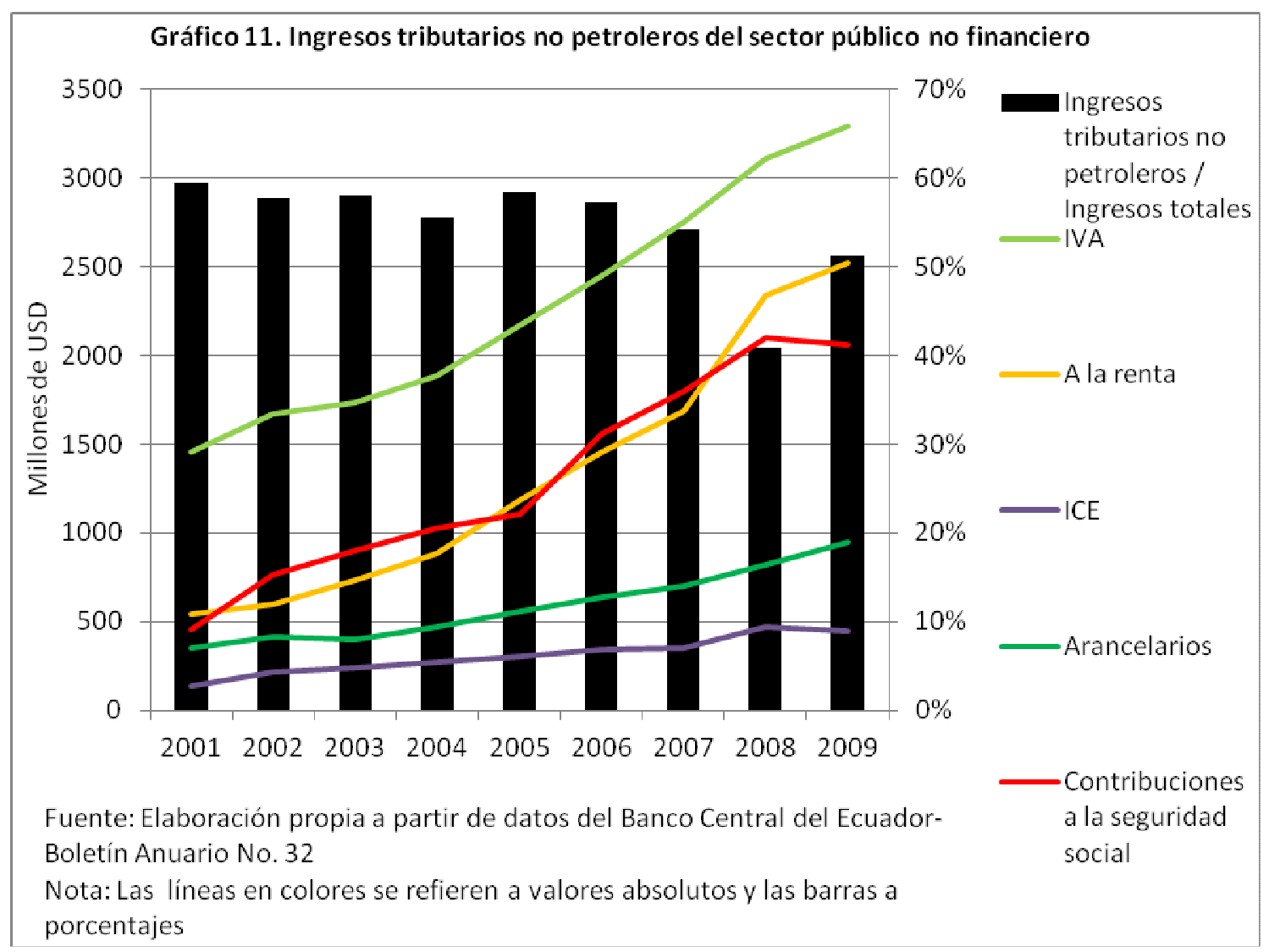


Bäckström, Caroline. Evolución y tendencias del rentismo petrolero en el ecuador 2001-2010.

La Fiscalidad Relativa Ponderada $(F R P)^{18}$ en el Sector Público no Financiero aumentó fuertemente a partir del 2007 con la subida del petróleo y el aumento de la participación del Estado en la renta petrolera. Así, la FRP era de 1,5 en el 2007, 2,7 en el 2008 y 2 en el 2009. Un mayor nivel de FRP significa que la importancia de los ingresos petroleros en los ingresos fiscales aumentó más que el peso del sector petrolero en la economía. (Gráfico 12)

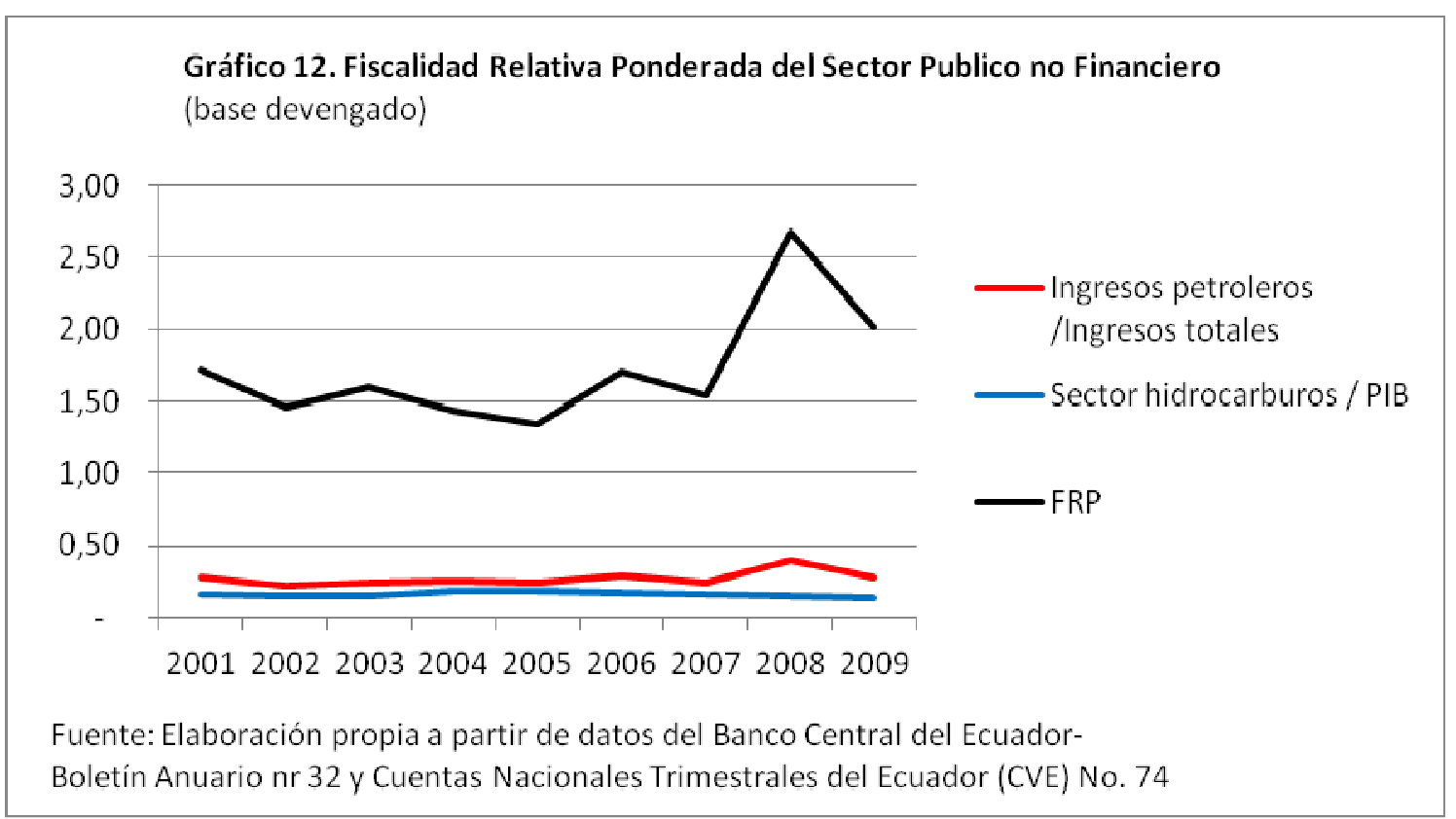

\subsubsection{Gastos públicos e inversión}

Los gastos públicos aumentan durante todo el periodo, tanto en valores absolutos como en peso del PIB, pero de forma más acentuada a partir del 2007, y son los gastos corrientes los que más aumentan a partir del ese año (Gráfico 13).

Sin embargo, a partir del 2007, los gastos corrientes perdieron peso en los gastos totales a favor de los gastos en capital. Así, el gasto en capital del Sector Público No Financiero pesó $20 \%$ en el 2006 y $32 \%$ en el 2009, superando con poco la importancia que tuvo en el 2001. (Gráfico 14).

En cuanto a los gastos corrientes, que aumentan fuertemente a partir del 2007, son otros gastos corrientes los que más crecen a partir del 2007. En estos están las transferencias corrientes realizadas por las unidades institucionales, el pago del bono solidario, la importación de derivados para consumo interno y los gastos no operacionales ejecutados por las empresas públicas no financieras. (Banco Central del Ecuador, 2011) Los sueldos dominan y también crecen más a partir del 2007, de acuerdo con la ampliación del aparato administrativo público. Además crecen, aunque no tan fuerte, las compras de bienes y servicios y las transferencias de la Seguridad Social, en línea con los extensos programas sociales introducidos a partir del 2007. (Gráfico 15)

\footnotetext{
${ }^{18} \mathrm{FRP}=$ Fiscalidad petrolera / (sector de petróleo/PIB)
} 
Bäckström, Caroline. Evolución y tendencias del rentismo petrolero en el ecuador 2001-2010.
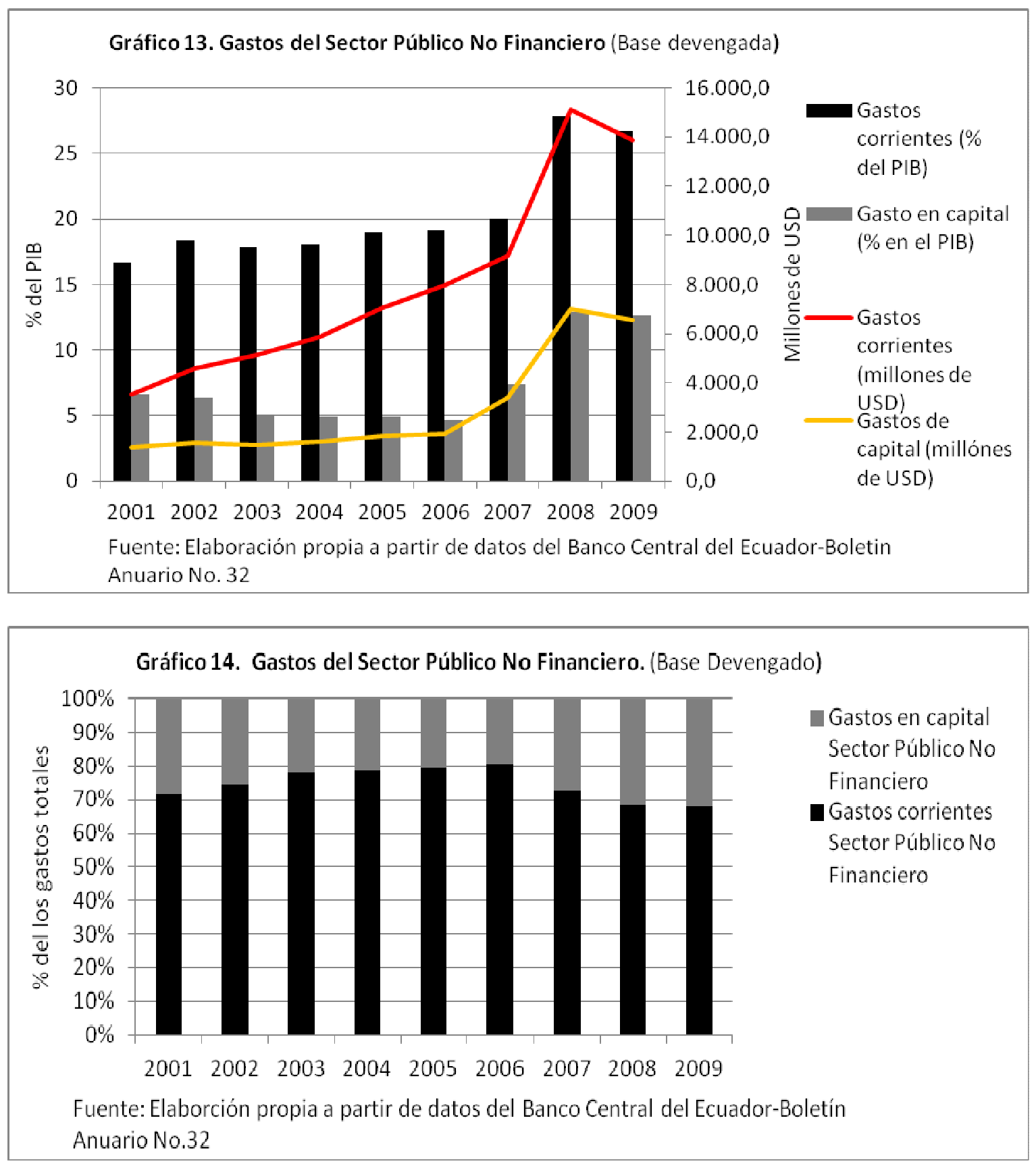

En los gastos en capital se ve que la Formación Bruta de Capital crece más fuertemente después del 2007, siendo ésta ejecutada sobre todo por el Gobierno Central, pero también por las empresas públicas y menos por los gobiernos seccionales. Cuando el precio del petróleo cae en el 2008, son únicamente los gastos en capital de las empresas públicas las que se mantienen. (Gráfico 16)

No se ha podido encontrar datos más desagregados de los gastos de capital, sin embargo los datos de egresos fiscales del gobierno central ofrecen otro tipo de clasificación que nos puede ayudar a entender hacia dónde se han dirigido los gastos públicos. En éstos se puede ver que los gastos en desarrollo urbano y vivienda son los que más crecen entre 2006-2009, aumentando un $86 \%$. También los egresos en turismo y en recursos naturales y energéticos aumentaron un $82 \%$ y un $76 \%$ respectivamente en el mismo periodo, aunque éstos, en valores absolutos, 
Bäckström, Caroline. Evolución y tendencias del rentismo petrolero en el ecuador 2001-2010.

son mucho menos importantes que los egresos en desarrollo urbano y vivienda. (Gráfico 17).
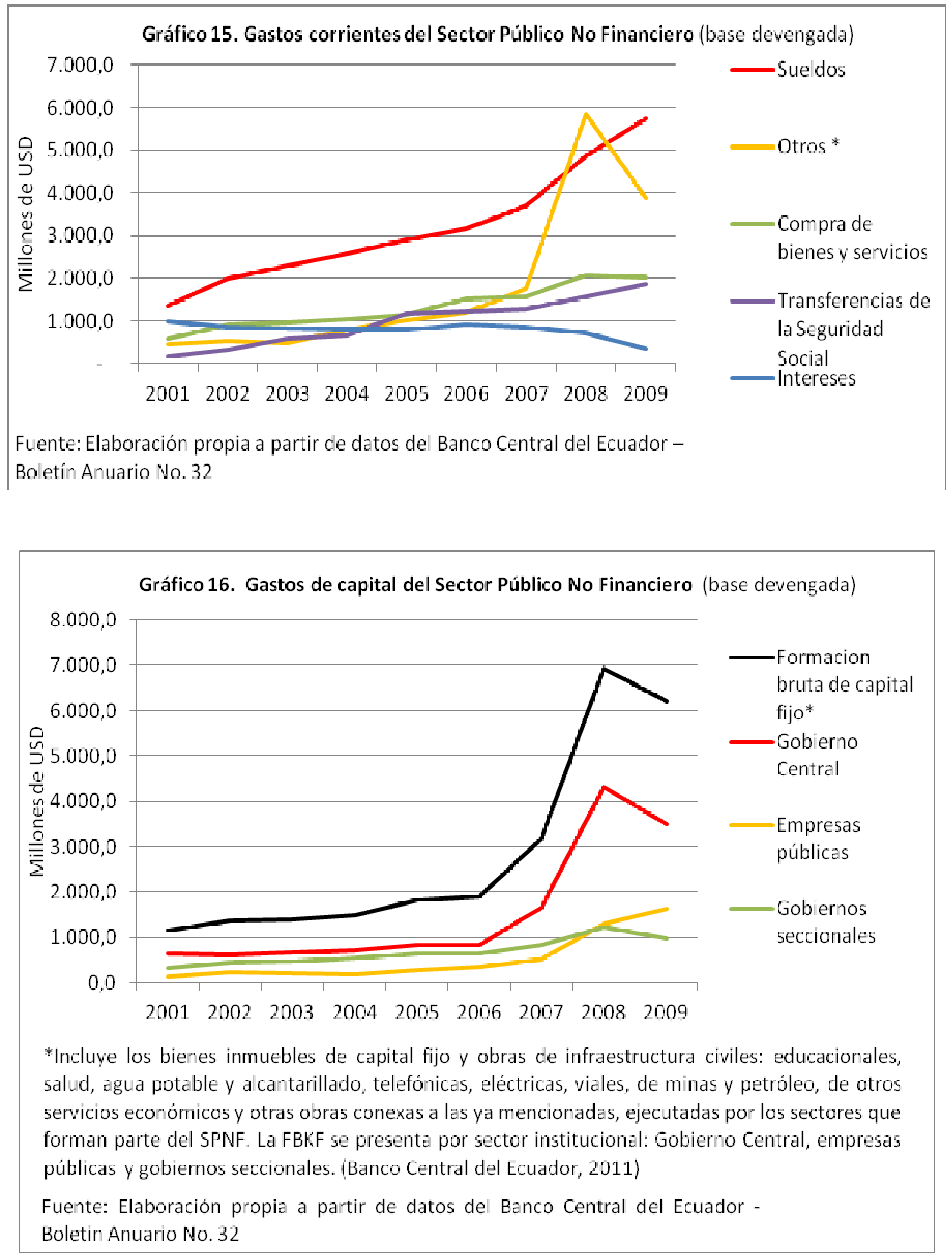

Papeles de Europa 
Bäckström, Caroline. Evolución y tendencias del rentismo petrolero en el ecuador 2001-2010.

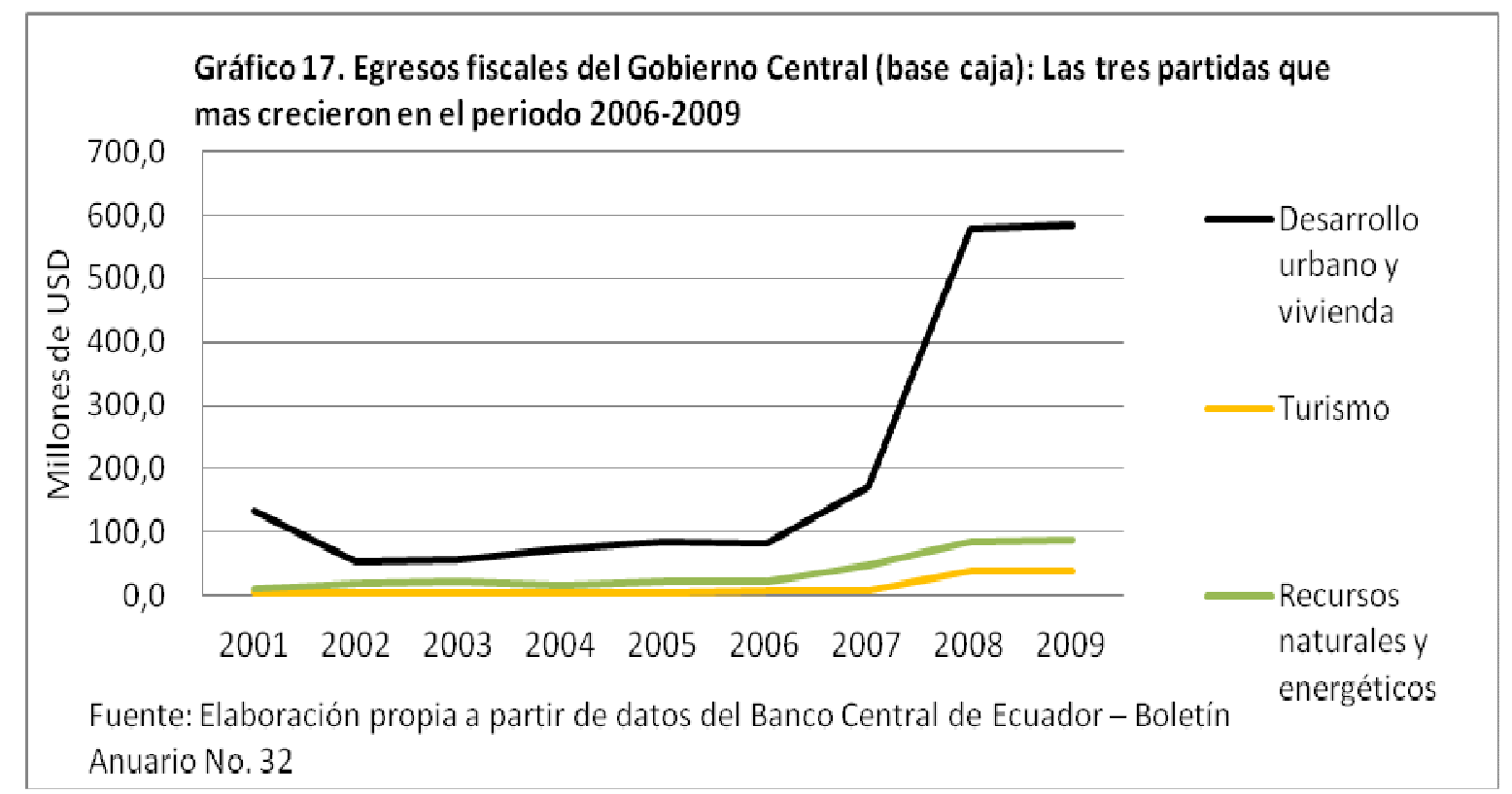

Las tres partidas más importantes de los egresos del Gobierno Central en el 2009 fueron servicios generales, educación y cultura además de deuda pública. De estos el que más crece a partir de 2006 son los servicios generales. Los egresos de educación y cultura también crecen aunque menos, mientras que los egresos de la deuda pública disminuyen. (Gráfico 18) Así, de las inversiones públicas más visibles para la población ecuatoriana durante el Gobierno de AP ha sido justamente la construcción de carreteras y viviendas para la población con menores ingresos. El aumento de la importancia de los gastos en servicios generales, confirma la ampliación del sector público.

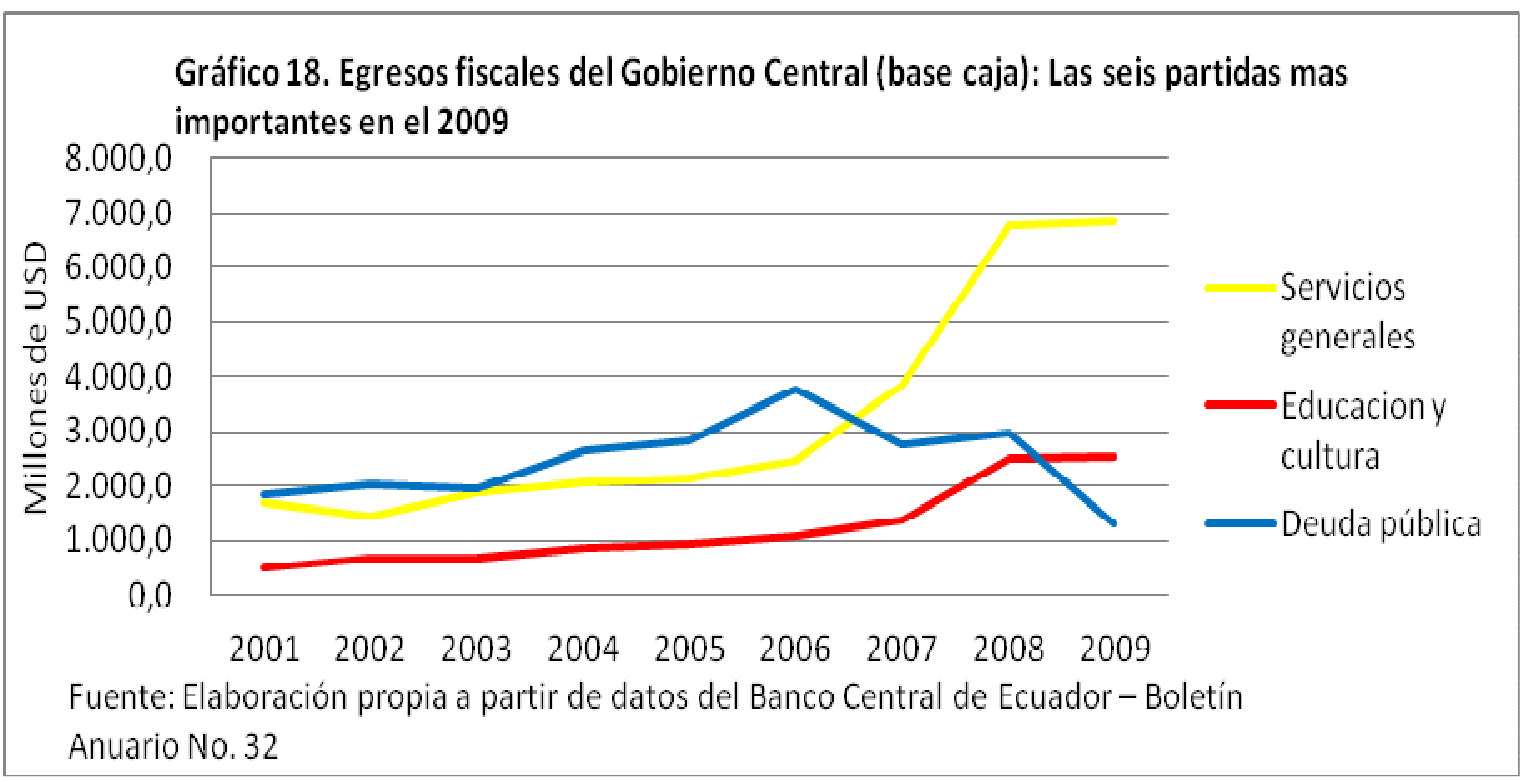

La inversión pública ganó peso en el PIB en prejuicio de la inversión privada. Así, la inversión pública aumentó su peso en el PIB de forma importante a partir del 2006, después de haber mantenido un peso reducido y estable los años anteriores. En cambio las inversiones privadas perdieron peso, disminuyendo a partir del 2006, de un 18\% del PIB a -11\% del PIB en el 2009 (Gráfico 19). La inversión privada en el Ecuador se vio reducida en parte, como consecuencia de la renegociación de los 
Bäckström, Caroline. Evolución y tendencias del rentismo petrolero en el ecuador 2001-2010.

contratos petroleros, lo cual desincentivó la inversión de empresas extranjeras petroleras. Por otro lado, los nuevos contratos establecen el requisito de que éstas inviertan en el sector. Sin embargo según algunos autores, el monto de la inversión requerida es de poca importancia. Así, las empresas petroleras extranjeras van a invertir 12000 millones de USD durante los cuatro próximos años, monto que equivale a lo que invirtieron solamente en el 2006, y que es demasiado bajo para impedir que la producción siga cayendo (The Economist ,2010).

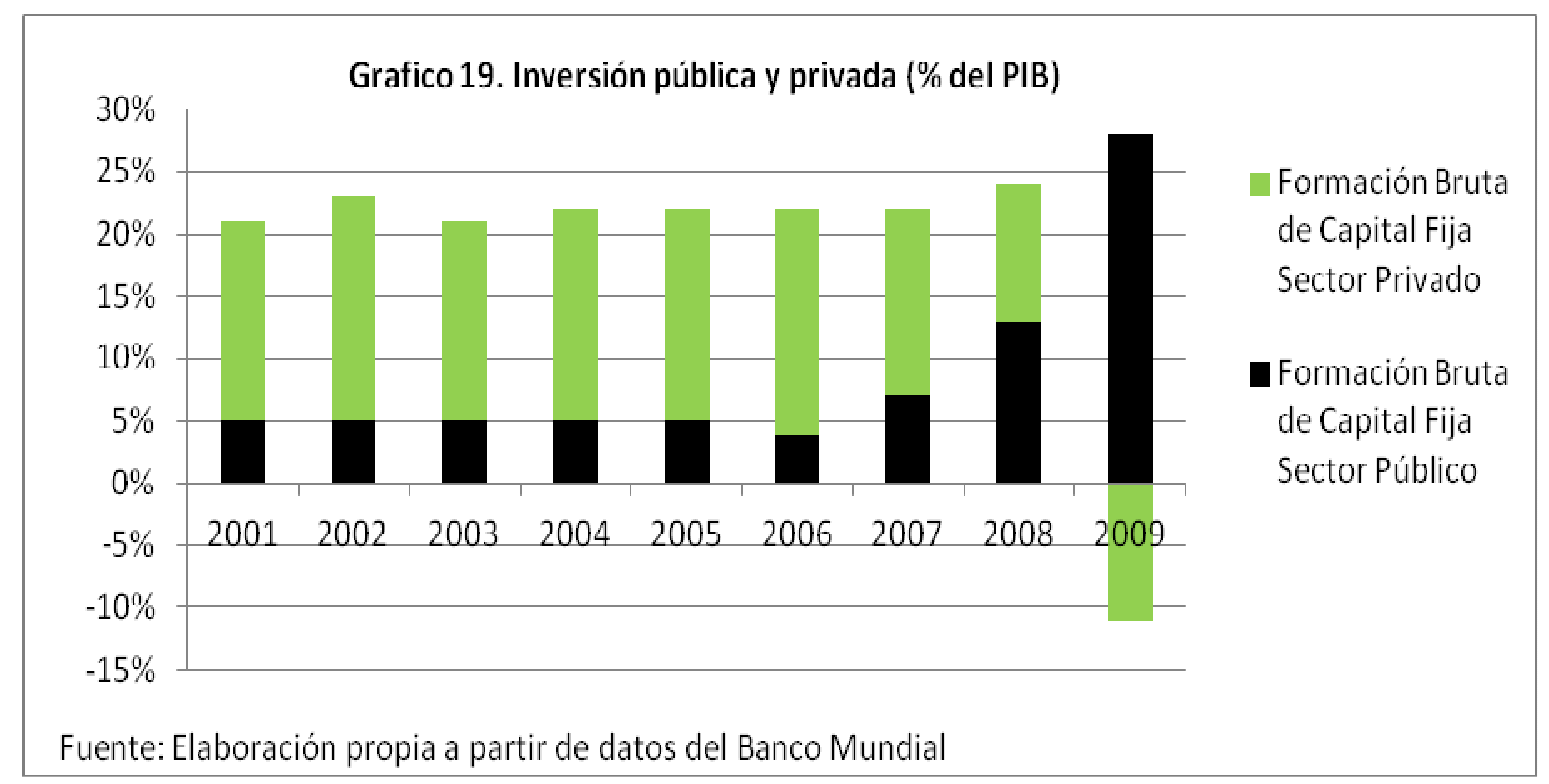

\subsection{Dependencia y volatilidad ante la evolución del precio de petróleo}

Como se puede ver en el gráfico 20, entre 2003 -2006 los componentes de la demanda evolucionan de acuerdo con el precio de petróleo, aunque manteniendo tasas de crecimiento por debajo de éste. Sin embargo, a partir del 2006 los componentes de la demanda se vuelven claramente más elásticos ante el precio de petróleo, especialmente la inversión pública, el gasto público y las importaciones. Los primeros dos incluso registran tasas de crecimiento superiores al del precio de petróleo. Los que menos aumentan sus elasticidades son el PIB, la inversión privada y el consumo (Gráfico 20).

En la tabla 6 se han calculado las elasticidades de los componentes de la demanda con respecto al precio y con respecto a la producción de petróleo en barriles, comparando dos periodos 2001-2005 y 2006-2009. Las elasticidades con respecto al precio pasan de ser inelásticas a ser elásticas, para todos los componentes de la demanda, destacando con muy altos valores la inversión pública, las importaciones y el gasto público. Esto refleja que la economía ecuatoriana se vuelve más dependiente y vulnerable ante la evolución del precio de petróleo a partir del 2006 y en particular los componentes relacionados con el ámbito público. La explicación se encuentra en la reforma del sector petrolero que significó una mayor dependencia de los ingresos fiscales del precio de petróleo, siendo estos canalizados al gasto y a la inversión pública a través de amplios programas sociales, incremento del aparato público administrativo y grandes proyectos públicos de inversión. La evolución de los componentes de la demanda con respecto a la producción de petróleo nos da resultados más variados, indicándonos que no es tanto la cantidad de petróleo 
Bäckström, Caroline. Evolución y tendencias del rentismo petrolero en el ecuador 2001-2010.

producido la que determina los componentes de la demanda como la evolución del precio de petróleo (Tabla 6).

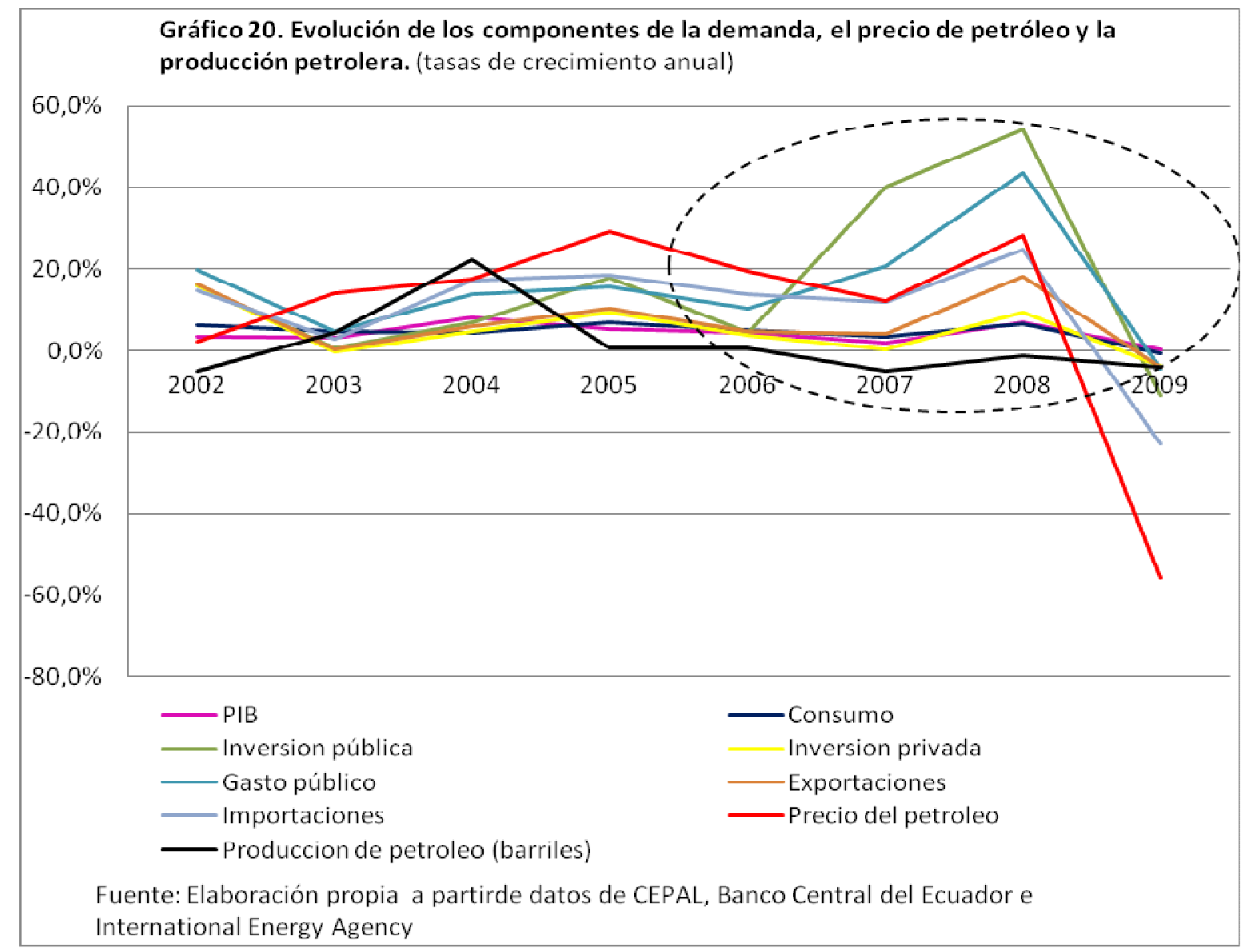

\begin{tabular}{|lcccc|}
\hline \multicolumn{4}{|c|}{ Tabla 6. Elasticidad de los componentes de la demanda. } \\
& Con respecto al precio de petróleo & $\begin{array}{c}\text { Con respecto al volumen de } \\
\text { producción }\end{array}$ \\
\hline & $\mathbf{2 0 0 1 - 2 0 0 5}$ & $\mathbf{2 0 0 6 - 2 0 0 9}$ & $\mathbf{2 0 0 1 - 2 0 0 5}$ & $\mathbf{2 0 0 6 - 2 0 0 9}$ \\
\hline PIB & 0,2 & 4,8 & 0,8 & 1,0 \\
\hline Consumo & 0,2 & 4,9 & 0,9 & 1,1 \\
\hline Inversión Publica & 0,5 & 112,2 & 1,9 & 24,0 \\
\hline Inversión privada & 0,4 & 3,2 & 1,3 & 0,7 \\
\hline Gasto público & 0,8 & 55,8 & 10,1 & 11,9 \\
\hline Exportaciones & 1,0 & 4,7 & 3,5 & 1,0 \\
\hline Importaciones & 0,8 & 60,3 & 2,7 & 2,4 \\
\hline $\begin{array}{l}\text { Fuente: Cálculos propios a partir de datos de CEPALSTAT, International Energy Agency y Banco } \\
\text { Central del Ecuador }\end{array}$ & & & & \\
\hline
\end{tabular}

Así, en periodos de bonanza el comercio exterior influye de forma más importante en el crecimiento del PIB a partir del 2006. El alto nivel de fiscalidad petrolera hace que esta bonanza se canalice a los ingresos públicos. Ya que éstos a partir del 2006 dependen más del precio de petróleo, la evolución del gasto público y de las inversiones públicas también dependen más del precio de petróleo, lo cual da lugar 
Bäckström, Caroline. Evolución y tendencias del rentismo petrolero en el ecuador 2001-2010.

a dificultades en la gestión del presupuesto público, debido al carácter fluctuante de los ingresos. Las elasticidades del consumo, de la inversión privada y del PIB son las que se ven menos afectadas por el mayor nivel de rentismo.

\section{CONCLUSIONES: ¿AUMENTÓ EL GRADO DE RENTISMO EN EL ECUADOR A PARTIR DEL 2007?}

Como se mencionó en la introducción, desde el descubrimiento de nuevos yacimientos petroleros en la década de los setenta, junto con los picos de petrolero que se han dado desde entonces, Ecuador ha sido receptor de grandes cantidades de renta externa proveniente de la exportación de petróleo, renta que además aumentó su importancia en la economía entre 2001-2010.

Ecuador mantiene su condición de mono-exportadora de crudo a lo largo del periodo, ya que tanto el peso de las exportaciones petroleras en el total de las exportaciones como el peso de las exportaciones de crudo en las exportaciones petroleras no se alteraron de forma importante entre 2001-2010. Además, el porcentaje de la producción petrolera que se destina a la exportación creció durante todo el periodo, lo cual refleja la necesidad que tiene el país de recibir los ingresos de la exportación de petróleo y cómo el aprovisionamiento de petróleo y derivados para el consumo interno queda fuera de las prioridades. Esto está relacionado con la poca capacidad de refino que tiene Ecuador, por lo cual para satisfacer la demanda de derivados se ve obligado a importarlas.

El país tiene una economía poco diversificada, condición clave para ser considerado rentista, aunque su grado de diversificación no se vio alterado entre 2001-2010. Además, el sector petrolero es importante para la economía ecuatoriana a pesar de no tener el mismo peso en el PIB como los países rentistas por excelencia. Sin embargo, este sector perdió peso en el PIB durante el periodo analizado.

El ya importante sector de servicios creció en estos años y, en particular, el comercio y los servicios relacionados con el sector público, como la ampliación del sector de obras públicas y el del gobierno general. Estos crecieron más fuertemente a partir del 2007, nutriéndose de crecientes importaciones de bienes de capital y bienes de consumo que también muestran un crecimiento más fuerte a partir del 2007 . El sector manufacturero ecuatoriano se mantuvo estancado e incluso disminuyó un poco su peso relativo.

Se ha podido confirmar la escasa capacidad del sector petrolero de generar empleo, lo cual nos indica que sólo una reducida parte de la población participa en la generación de la renta petrolera. Así, el porcentaje de la población que entre 20012010 estaba empleada en el sector petrolero se mantuvo muy por debajo del porcentaje de personas ocupadas en el sector de servicios, que además aumentó. Además, el sector manufacturero redujo levemente su capacidad de absorción de empleo, contribuyendo a que se agrave la concentración de la población empleada en el sector de servicios, sector que además es poco productivo.

Hemos visto como la ENP ecuatoriana aumenta fuertemente su peso en el sector petrolero tanto en la producción y exportación, como en la participación en la renta generada. El papel de Petroecuador EP se fortalece con la reestructuración del 
Bäckström, Caroline. Evolución y tendencias del rentismo petrolero en el ecuador 2001-2010.

sector petrolero, convirtiéndose la empresa en el principal explotador y exportador de petróleo del país. Así, la reestructuración del sector redujo la importancia de las empresas extranjeras, dando incluso lugar a que algunas abandonasen el país. Sin embargo, hay quienes cuestionan que la reestructuración realmente implique una menor influencia de las empresas extranjeras, ya que los nuevos contratos en realidad las benefician, debido a requisitos de inversión muy bajos y tarifas por barril muy altas. En cualquier caso, dado que estos contratos se firmaron en el 2010, todavía es temprano para deducir los efectos de los mismos. Aquí nos basta constatar que en el periodo 2007-2010, en pleno proceso de renegociación de contratos petroleros, Petroecuador EP ganó peso en el sector en prejuicio de las empresas extranjeras, lo que contribuye a acentuar el rentismo. Además, para el gobierno de AP, Petroecuador EP es un instrumento clave para la generación de ingresos petroleros y el alcance de los objetivos de desarrollo establecidos en sus planes de desarrollo.

El triunfo de AP en las elecciones del 2006 y en el 2009, junto con la aprobación de la nueva constitución del 2008, significa que existe un consenso social que apoya el actual gobierno. La política de Rafael Correa, apoyada por la población, establece la necesidad de reformar el papel del Estado para que pueda tener como objetivo el bienestar colectivo, asegurando que todos los ecuatorianos tengan sus derechos asegurados y acceso a los servicios básicos. También se considera fundamental recuperar la capacidad de regulación y redistribución del Estado en la economía, así como la soberanía nacional sobre los recursos petroleros y la competitividad de sus empresas. Además, las ganancias extraordinarias del petróleo deben ser reguladas para su correcta redistribución social. De esta manera, a partir del 2007 existe un acuerdo de que el Estado ecuatoriano debe ser el principal receptor y distribuidor de la renta petrolera. La nueva Ley de Hidrocarburos establece que el Estado es el que tiene competencia exclusiva para el manejo de hidrocarburos y que explorará y explotará el petróleo a través de Petroecuador EP. Así, siendo propietario de Petroecuador EP y receptor de la fiscalidad petrolera, el Estado funciona como intermediario entre los que generan la renta y los que la disfrutan. Según la Visión de Hidrocarburos del Ministerio de Recursos No Renovables del Ecuador, el objetivo de la exportación de petróleo del Ecuador es obtener el máximo beneficio para el país, ya que se busca aumentar los ingresos petroleros para luego distribuirlos equitativa y justamente.

Dado que el Gobierno de AP obtuvo y mantiene el apoyo político del pueblo a través de su política de redistribución y gasto social, y que necesita mantener el nivel de los ingresos petroleros para poder financiar sus amplios programas sociales y de inversión, se puede deducir que la captura y la distribución de la renta están sujetas a criterios políticos cuyo objetivo es mantener esta dinámica rentista, legitimando la posición del Estado en el poder.

Los ingresos petroleros del Estado aumentaron de forma importante a partir del 2007, a pesar de que la fiscalidad petrolera se mantuvo constante, alrededor de un $30 \%$. Este nivel de presión fiscal está muy por debajo del de Kuwait, país rentista por excelencia, pero ha sido suficientemente significativo como para haber desincentivado la necesidad del Estado de extraer recursos del resto de la economía, ya que la presión tributaria es de las más bajas de los países latinoamericanos. El Gobierno de AP ha introducido medidas para aumentar los 
Bäckström, Caroline. Evolución y tendencias del rentismo petrolero en el ecuador 2001-2010.

ingresos tributarios no petroleros, lo cual aumentó fuertemente los ingresos del impuesto a la renta. Sin embargo el peso del conjunto de los ingresos tributarios no petroleros se redujo, por lo cual no se ha logrado reducir la dependencia de los ingresos petroleros. Además, dado que al mismo tiempo se busca aumentar los ingresos petroleros, parece que el Estado ecuatoriano, más que reducir su dependencia de los ingresos petroleros, busca aumentar ingresos por donde pueda. De esta manera la evolución de la fiscalidad petrolera parece depender más que nada de la evolución del precio de petróleo, canalizándose esta dependencia al gasto e inversión públicos.

En cuanto a la clasificación de "Estado de asignación de recursos" y "Estado productivo" hemos visto que en el caso del Ecuador la fiscalidad petrolera sólo superó el $40 \%$ en el 2008 . Sin embargo, independientemente de la validez de este límite, se puede constatar que, dado que el peso de los ingresos petroleros en los ingresos totales se mantuvo y que el peso del gasto en el PIB aumentó de forma importante a partir del 2007, Ecuador mostró una tendencia hacia ser un Estado de asignación, es decir un Estado cada vez más rentista y menos productivo. Además, según el indicador FRP, el grado de rentismo aumentó a partir del 2007 debido a que la fiscalidad petrolera se mantuvo constante y el peso del sector en el PIB disminuyó.

En paralelo con los mayores ingresos públicos a partir del 2007 y en particular los ingresos del petrolero, aumentaron también los gastos del Estado. Así, los ingresos provenientes de las exportaciones petroleras se han traducido en políticas de gasto que han servido como instrumento de intervención pública y han ayudado a legitimar la posición del Gobierno, que así ha logrado mantener el apoyo de la mayoría del pueblo.

Dado que crecieron tanto los gastos en capital como los corrientes, los mayores ingresos petroleros del Estado se destinaron tanto a actividades productivas como no productivas. Los gastos corrientes han sido sobretodo dedicados a programas sociales, importación de derivados y aumento de los sueldos, encajando esto con la dinámica de un estado rentista que mantiene su apoyo gracias a gastos sociales, que necesita de importaciones de derivados y que expande su sistema burocrático. Por otro lado, los mayores gastos en capital muestran un esfuerzo de invertir, sin embargo, ya que no se han conseguido datos más desagregados, es difícil evaluar estos gastos. Se sabe que se han construido carreteras y viviendas y que se ha invertido de forma importante en el sector petrolero. Las nuevas carreteras sí tienen un cierto impacto en la productividad mientras que el impacto en la productividad de la vivienda es escaso. Las inversiones en el sector petrolero aumentan la productividad únicamente de ese sector, pero también profundizan la especialización de la economía hacia el sector extractivo. Además, la inversión privada disminuyó de forma importante durante el periodo y todavía es difícil saber cuál será el impacto de los nuevos contratos petroleros en la evolución de la inversión privada, pero serán inversiones limitadas al sector petrolero que, junto con el esfuerzo del Gobierno de invertir en el sector, profundizarán la especialización productiva petrolera del país.

La evolución del PIB y los componentes de la demanda se vuelven elásticos al precio de petróleo a partir del 2006. Sobre todo los componentes relacionados con el 
Bäckström, Caroline. Evolución y tendencias del rentismo petrolero en el ecuador 2001-2010.

sector público y las importaciones. Así, la economía ecuatoriana se volvió más vulnerable y dependiente ante la evolución del precio de petróleo y de la economía internacional.

De esta manera, se puede concluir que el grado de rentismo petrolero del Ecuador aumentó a partir del 2007, como resultado de las políticas llevadas por el Gobierno de AP. Sobre todo se fortalecieron los rasgos relacionados con el sector público y los objetivos de la gestión de la renta así como aumentó fuertemente la dependencia y vulnerabilidad de los componentes de la demanda a la evolución de los precios de petróleo. A pesar de los esfuerzos del gobierno por mejorar la captación de ingresos no petroleros e invertir en capital, estos no parecen haber sido lo suficientemente importantes como para contrarrestar el fortalecimiento del resto de las características de una economía rentista. Además, los rasgos relacionados con la estructura económica se mantuvieron, en general, constantes.

Para fomentar el desarrollo socio-económico, una economía rentista necesita hacer frente a los siguientes tipos de gastos: reproducción del sector extractivo, gasto social, fortalecimiento de la capacidad de refino e implementación de políticas de diversificación. El análisis profundo de hasta qué punto el Gobierno ecuatoriano está fomentando el desarrollo desborda el límite de este trabajo. Sin embargo, sabemos que el Gobierno de AP, con su mayor capacidad de captura de la renta petrolera, ha actuado sobre todo por las primeras dos vías y tiene intenciones de actuar por las dos últimas. Hay que tener en cuenta que dado los pocos años de AP en el poder y la lentitud con la que las reformas suelen activarse, todavía es pronto para ver los resultados de sus políticas. Así, aquí nos basta concluir que con un mayor control de los ingresos petroleros por parte del Estado ecuatoriano, estos pueden, si son gestionados adecuadamente, contribuir a la mejora de las condiciones de vida de la población. Sin embargo, queda por ver si el mayor grado de rentismo es una primera fase de mejoras sociales, previa a una reestructuración productiva, que por ahora no se ha dado. Así, es importante que el Estado no pierda de vista el objetivo de un crecimiento económico sostenible a través de la diversificación de la estructura económica y mejora de la productividad, teniendo en cuenta que los ingresos petroleros son muy fluctuantes y no están garantizados a largo plazo. 
Bäckström, Caroline. Evolución y tendencias del rentismo petrolero en el ecuador 2001-2010.

\section{BIBLIOGRAFÍA}

Acosta, A. (2009): "La maldición de la abundancia" Ediciones Abya-Yala. Quito, Ecuador

Acosta, A (2011): "Ecuador: Unas reformas petroleras con muy poca reforma", Ecuador Debate 82, abril 2011, p. 45-60

Allison, (2011): "Ecuador: $5^{\circ}$ país con mayor participación en la renta petrolera" extraído el 2011-09-15 de www.lamula.pe

Banco Central del Ecuador (2011): "Metodología de la información estadística mensual", 3ra Edición

CEPAL (2007): "La tributación directa en América Latina y los desafíos a la imposición sobre la renta", División de Desarrollo Económico

CEPAL (2008): "Renta petrolera y minera en países seleccionados de América Latina", Documento de Proyecto

CEPAL (2009): "Tributación directa en Ecuador. Evasión, equidad y desafíos de diseño", Serie Macroeconomía del desarrollo No. 85

Estrada Mañé. A. y de la Cámara Arilla, C. (2004): "Rusia: ¿Hacia una economía petrolera-rentista?, Universidad de Barcelona

Machín Álvaréz, A. (2010): "Rentierism in the Algerian economy based on oil and natural gas", Energy Policy

Ministerio de Recursos No Renovables del Ecuador, MRNR. (2009): "Visión de Hidrocarburos" extraído el 2011-09-02 en http://www.mrnnr.gob.ec/index.php?option=com_content\&view=article\&id=468\% 3 Avision-de-hidrocarburos\&catid $=58 \% 3$ Ahidrocarburos\&ltemid=37\&lang=es

Ministerio de Recursos No Renovables del Ecuador, MRNR (2011): "Contratos Petroleros" extraído el 2011-09-02 "Con http://www.mrnnr.gob.ec/index.php?option=com_content\&view=article\&id=1022\& Itemid $=132 \&$ lang $=$ es

Movimiento Alianza País (2011): "Manifiesto AP" extraido el 2011-09-02 en http://movimientoalianzapais.com.ec/pagina-ejemplo-2/manifiesto-ap/

Movimiento Alianza País (2011): "Programa de Accion" extraído el 2011-09-02 en http://movimientoalianzapais.com.ec/pagina-ejemplo-2/programa-de-accion/

Naciones Unidas (2009): "Clasificación Industrial Internacional Uniforme de todas las actividades económicas (CIIU)", Revisión 4

OPEP (2011a) "Annual Statistical Bulletin 2010/2011"

OPEP (2011b): "Brief History". Extraído 2011-06-24 en http://www.opec.org/opec_web/en/about_us/24.htm

Ordoñez, A., Pantoja, M. y López, J. (2010): "Arreglos institucionales en el sector extractivo: Principales elementos conceptuales y experencias internacionales", Hablemos de Políticas, Nr. \&, Grupo FARO, Quito-Ecuador

Petroecuador EP (2009): "Presupuesto 2010"

República del Ecuador (2007a): "Plan Nacional de Desarrollo 2007-2010Planificación para la revolución ciudadana"

República del Ecuador (2007b) "Ley Reformatoria para la Equidad Tributaria en Ecuador"

República del Ecuador (2009): "Plan Nacional del Buen Vivir 2009-2013Construyendo un Estado Plurinacional e Intercultural", Versión Resumida

República del Ecuador (2010): "Proyecto de Ley Reformatoria a la Ley de Hidrocarburos y a la Ley de Régimen Tributario Interno"

Servicio de Rentas Internas (2007): "Información sobre la Reforma Tributaria" 
Bäckström, Caroline. Evolución y tendencias del rentismo petrolero en el ecuador 2001-2010.

The Economist (2010):“Ecuador's oil industry: If it ain't broke...”, Americas view blog Varela, M. (2010): "Las actividades extractivas en Ecuador", Ecuador Debate, no.79, p. $127-150$

Yates, D.A. (1996): "The theory of the rentier state" en "The rentier state in Africa: Oil rent dependency and neocolonialism in the republic of Gabon", African World Press

\section{Fuentes estadísticas}

Banco Central del Ecuador: http://www.bce.ec/contenido.php?CNT=ARB0000003

- Boletín Anuario No. 32

- Cuentas Nacionales Trimestrales del Ecuador (CVE) No. 74

- Boletín trimestral de balanza de pagos del Ecuador No. 32

- Cifras del Sector Petrolero Ecuatoriano

Banco Central de Venezuela: http://www.bcv.org.ve/c2/indicadores.asp

Banco Mundial: http://datos.bancomundial.org/

Comisión Económica para América Latina: http://websie.eclac.cl/infest/ajax/ cepalstat.asp

International Energy Agency: http://www.iea.org/stats/index.asp 